\title{
REGENERACIÓN, ECONOMÍA POLÍTICA Y EDUCACIÓN EN LA MONARQUÍA ESPAÑOLA DEL SIGLO XVIII. CONCEPTOS EN LA DELIMITACIÓN DE UN CAMPO SEMÁNTICO
}

\author{
Regeneration, political economy and education \\ in the Spanish monarchy during the eighteenth century. \\ Concepts in the delimitation of a semantic field
}

\author{
Adriana MILANO \\ adria_milano@yahoo.com.ar
}

Fecha de recepción: 20/04/2017

Fecha de aceptación definitiva: 27/07/2017

RESUMEN: Durante las reformas borbónicas la modernización y la secularización estuvieron entre los pilares de un plan general de restauración de una situación de decadencia que comenzó a evaluarse desde el siglo anterior. En ese contexto, conceptos como el de educación formaron parte de una agenda de discusiones nutrida por la Ilustración española y el fomento de medidas reformadoras. En este artículo se analiza la evolución del concepto de educación en el siglo XVIII, su relación con el ideal de regeneración y la conexión con el auge del pensamiento de la economía política. Se busca delimitar la trama semántica en que tal concepto se presenta en conexión con otros, opuestos o paralelos; se abordan las reformas concretas del proceso de secularización y modernización educativa, a la vez que se alude a las distintas formas de sociabilidad y circulación de ideas que permitieron su discusión en ámbitos diversos de la Monarquía Hispánica.

Palabras claves: historia conceptual; regeneración; educación; Ilustración española; economía política; secularización. 
REGENERACIÓN, ECONOMÍA POLÍTICA Y EDUCACIÓN EN LA MONARQUÍA ESPAÑOLA DEL SIGLO XVIII...

ABSTRACT: During the Bourbon reforms modernization and secularization were among the bases of a general plan for remedying a situation of decay which had been detected since the previous century. In that framework, concepts such as education had significance in the debates generated by the Spanish Enlightenment and the development of reforms. In this piece of workwe analyse the evolution in the concept of education during the eighteenth century, its relationship with the regeneration ideal and its connection with the rise of the political economy debates. The work pursues the delimitation of the semantic field in which that concept is included in connection with others, opposite or parallel, also the reforms entailed by the process of secularization and educational modernization in addition to the different forms of sociability and circulation of ideas that allowed discussions in Spain.

Key words: conceptual history; regeneration; education; Spanish Enlightenment; political economy; secularization.

\section{INTRODUCCIÓN}

El prólogo a una reciente compilación acerca de la relación entre conceptos políticos, tiempo e historia advierte que resulta de suma importancia al momento de emprender el análisis de sociedades del pasado, tomar en cuenta la variabilidad de las redes semánticas que los hombres tejieron y destejieron en el espacio y en el tiempo. Al mismo tiempo, recuerda que acertadamente Martin Burke y Melvin Richter alertaron sobre la imposibilidad radical de traducir cabalmente el pensamiento político y social sin un conocimiento previo de los significados históricos de los conceptos ${ }^{1}$.

Por otra parte, Reinhart Koselleck advirtió que los conceptos integran un campo de lucha semántica que corresponde a todas las épocas de crisis que se conocen por fuentes escritas. En esa lucha se busca definir posiciones políticas o sociales y mantener el orden o imponerlo. Los conceptos no sólo conciben los hechos de tal o cual manera, sino que se proyectan hacia el futuro ${ }^{2}$.

Bajo tales premisas el objetivo de este trabajo es buscar un acercamiento a la delimitación del campo semántico del concepto de educación en la monarquía española del siglo XVIII. Los conceptos de decadencia y regeneración emergen del contexto de crisis desatado en la transición entre la monarquía de los Habsburgo y la dinastía de los Borbones, en un marco de reflexión iniciado por los novatores y continuado por los ilustrados españoles donde la economía política española,

1. Fernández Sebastián, Javier y Capellán de Miguel, Gonzalo (eds.). Conceptos políticos, tiempo e historia. Nuevos enfoques en historia conceptual. Madrid: Santander Editorial, Universidad de Cantabria, McGraw Hill Interamericana de España, 2013, pp. XVII-XVIII.

2. Koselleck, Reinhart. "Historia conceptual e historia social». En Futuro Pasado. Para una semántica de los tiempos históricos. Barcelona: Ediciones Paidós, 1993, p. 111. 
influenciada por los ilustrados napolitanos, jugó un rol esencial. Policía, comercio y orden, entre otros conceptos, aparecen en los escritos intelectuales, de circulación semiespecializada y popular, al igual que en la legislación. La tarea aquí propuesta es poner a la educación en juego dentro de ese nuevo campo de significaciones. Al momento de acercarnos a las fuentes textuales aquí seleccionadas, nos resulta pertinente una advertencia de J. G. A. Pocock. Nos referimos a la de atender a la posibilidad de que aquello que a primera vista podría parecer una forma de expresión de alto contenido idiosincrático era ya, o llegaría a ser, una fuente conocida por la comunidad discursiva, un "lenguaje disponible» que usaba y creía útil más de un actor de esa comunidad ${ }^{3}$.

Una perspectiva de cambio en el horizonte de expectativa, en términos de Reinhardt Koselleck, como dijéramos, puede verse en la cultura española en el periodo comprendido entre la extinción de la rama española de los Habsburgo y la llegada de los Borbones en el seno de la Monarquía Hispánica. A partir de las nociones de espacio de experiencia y horizonte de expectativa se ha buscado explicar cómo la semántica escatológica de la Monarquía Hispánica quedó inserta en la modernidad durante la Ilustración, mediante la adopción de una conciencia de decadencia y su superación, de una nueva temporalidad que vinculaba el pasado imperial mitificado con un futuro de engrandecimiento; reflexión impulsada ya desde fines del siglo XVII por los novatores ${ }^{4}$. La monarquía española de los Borbones promovió una imagen nueva, distintiva, en la cual la preocupación por la economía, la prosperidad y el comercio fue decisiva 5 .

Los novatores, como grupo de pensadores previo a la Ilustración española, estuvieron entre los primeros en señalar el contraste entre la situación hispana y

3. Pocock, J. G. A. «El concepto de lenguaje y el métier d'historien: reflexiones en torno a su ejercicio". En Pensamiento político e historia. Ensayos sobre teoría y método. Madrid: Ediciones Akal S.A., 2011, p. 109; Pocock, J. G. A. "Concepts and discourses. A difference in culture? Comment on a paper by Melvin Richter». En HARMut, Lehmann y RICHTER, Melvin (eds.). The meaning of historical terms and concepts. New studies in Begriffsgeschichte. Washington: German Historical Institute, 1996, p. 52. Sobre los conceptos políticos resulta interesante además: CHIGNola, Sandro. "Historia de los conceptos e historiografía del discurso político». Res Pública, 1998, 1, pp. 7-33.

4. SAnChez León, Pablo. "Decadencia y regeneración. La temporalidad en los conceptos fundamentales de la modernidad española». En Fernández Sebastián, Javier y Capellán de Miguel, Gonzalo (eds.). Conceptos políticos, pp. 272-300.

5. PÉrez SAmper, María Ángeles. "La imagen de la monarquía española en el siglo XVIII". Obradoiro de bistoria moderna, 2011, 20, pp. 136; 105-139. 
la evolución europea ${ }^{6}$. Dentro de la historiografía se les reconoce sus aportes para pensar los conceptos de decadencia y renovación en la Monarquía Hispánica ${ }^{7}$.

En los apartados siguientes veremos que la reflexión evolucionó por otras vías durante el periodo Ilustrado ${ }^{8}$. Con especial apertura hacia la economía política, el concepto de educación tuvo una construcción particular en relación a otros conceptos; todo ello en el marco de medidas concretas para el saneamiento y regeneración de la Monarquía Hispánica.

Cabe aclarar que la historia conceptual, por su cercanía con la historia intelectual, no puede considerarse alejada de la historia cultural. El acercamiento a un concepto requiere reparar en la situación de discurso en que aparece (no obstante los análisis sobre adherir a un tipo de historia u otra, como William Bouwsma aconsejara inclinarse por historia cultural en lugar de historia intelectual; o bien hablar de una nueva historia intelectual-cultural), es decir, en su "contexto". Para interpretar los textos es necesario comprender el contexto histórico en el cual fueron enunciados. Tal contexto tiende a ser multidimensional: una situación política específica, un entorno social o cultural preciso, un contexto institucional dado, etcétera, lo que se denominó como "contexto discursivo" ${ }^{9}$. Semejante reconstrucción

6. Sobre los novatores en sus diferentes aportaciones: Álvarez DE MIRANDA, Pedro. «La época de los novatores, desde la historia de la lengua». Studia Historica. Historia Moderna, 199614 (ejemplar dedicado a: Los novatores como etapa histórica), pp. 85-94; ÁlVAREZ DE MiRANDA, Pedro. «La revolución de los conceptos». En Ramos SAnTANA, Alberto y Romero Ferrer, Alberto (coords.). Cambio político y cultura en la España de entresiglos, 2008, pp. 201-218; ÁlvareZ DE MirandA, Pedro. "Las academias de los Novatores». En RodríGuez, Evangelina (coord.). De las Academias a la Enciclopedia: el discurso del saber en la modernidad, 1993, pp. 263-300; MESTRE SANCHÍs, Antonio y LA PARRA López, Emilio. "Los ilustrados valencianos». En Hermosilla PLA, Jorge (coord.). La ciudad de Valencia: historia, geografia y arte de la ciudad de Valencia. Valencia: Universidad de Valencia, 2009, tomo 1 pp. 387-391.

7. Entre los estudios recientes de los novatores, tributarios de los trabajos de Antonio Mestre Sanchís: Pérez García, Pablo y CATAlá SANZ, Jorge. «Renovación intelectual y prestigio social: novatores, academias e instituciones públicas en la Valencia de finales del siglo XVII y principios del XVIII». Saitabi, Universidad de Valencia, 2008, 58, pp. 219-250. También: Mestre SANCHís, Antonio. "Los novatores como etapa histórica». Studia Historica: Historia Moderna, 1996, Ediciones Universidad de Salamanca, 14 , p. 13.

8. Acerca de los estudios sobre la Ilustración: Bolufer Peruga, Mónica. «Qué es Ilustración?: nuevas perspectivas historiográficas sobre una vieja pregunta». Debats, 2009, 105, pp. 166-176. Para reflexionar sobre el siglo XVIII es inspirador: IGLESIAS CANO, María del Carmen. Razón y sentimiento en el siglo XVIII. Real Academia de la Historia, 2001. Sobre tendencias contrarias a la Ilustración: EGIDO LóPEZ, Teófanes. "Los antiilustrados españoles". Investigaciones Históricas: Época Moderna y Contemporánea, 1988, 8, pp. 121-142

9. Para esclarecer y profundizar sobre el tema: BRETT, Annabel. "What is Intellectual History Now?»; En Cannadine, David (ed.). What is History now? Palgrave Macmillan Ltd., 2002, pp. 113-131; Brett, Annabel; Tully, James y Hamilton-Bleakley, Holly. Rethinking the foundations of Modern political thought. Cambridge University Press, 2006; Benigno, Francesco. Las palabras del tiempo. Un ideario para pensar históricamente. Catedra, 2013; FERNÁNDEZ SEBASTIÁN, Javier. "QQué es un diccionario histórico de conceptos políticos?». Anales, 2004-2005, 7-8, pp. 223-240; FERNÁNDEZ SEBASTián, Javier. "Historia, historiografía, historicidad. Conciencia histórica y cambio conceptual». En SuÁREz CORTINA, Manuel (coord.). Europa del sur y América Latina: perspectivas historiográficas, 2014, pp. 35-64; 
no resulta fácil y es lo que intentamos aquí con un recorrido por instituciones, corpus normativos y reformas de la monarquía española del siglo XVIII en las cuales se insertó el concepto de educación en distintas enunciaciones que, de hecho, no podemos abarcar en estas páginas con toda exhaustividad dadas las innumerables fuentes que lo contienen.

\section{El CONCEPTO ESPAÑOL DE EDUCACION HASTA 1760}

Las medidas en materia educativa tomadas por la Monarquía Hispánica durante la primera mitad del siglo XVIII fueron escasas si se las compara con las aparecidas en los años siguientes. El proceso de secularización cultural y educativa que aconteció en España tomó a la educación formal como uno de los objetivos prioritarios de intervención y sus principales medidas comenzaron a partir de $1768^{10}$. Entre las disposiciones previas a ese periodo de reformas, en 1725 Felipe V estableció el Real Seminario de Nobles de Madrid dependiente del Colegio Imperial, a cargo de la Compañía de Jesús, para la enseñanza y educación de la "Noble juventud»"11. Respecto de un concepto de educación en la normativa en ese momento, al plantear que el objetivo de la norma era que los jóvenes aprendieran las primeras letras, lenguas, erudición y habilidades que condecoren a los nobles, se hizo mención a un objetivo expreso que vinculaba instrucción con una finalidad pública; "para que sirvan a la Patria con crédito y utilidad"; incluía cautelar los inconvenientes derivados de la libertad, ociosidad y diversión, por lo cual los seminaristas debían vivir en comunidad con distribución de horas y vigilancia inmediata de quienes actuarían como celadores ${ }^{12}$. El concepto de educación comienza así a asociarse a los conceptos de instrucción pública y utilidad: la educación se acercaba al concepto de Patria, como una herramienta en función de una finalidad pública puntual de mejorar la calidad del servicio de los nobles de la corte.

Años más tarde, en 1741, Felipe V introdujo novedades para mejorar la enseñanza de las primeras letras con prerrogativas, exenciones y requisitos que debían cumplir los maestros para acceder a su función educativa ${ }^{13}$. Los examinadores de

LEHMANN, Hartmut y RichTER, Melvin (eds.). The meaning of historical terms and concepts. New studies on Begriffsgeschichte. German Historical Institute, 1996; BuRKE, Peter. "La historia intelectual en la era del giro cultural». Prismas. Revista de Historia Intelectual, 2007, pp. 159-164.

10. Vergara Ciordia, Javier. "Jerarquía eclesiástica y secularización en el "Antiguo Régimen" (1768-1833)». Anuario de Historia de la Iglesia, 2010, 19, pp. 73-94.

11. Sobre aportes documentales e historiográficos acerca de colegios y bibliotecas de la Compañía de Jesús: Vergara Ciordia, Javier y SANCHEZ, Fermín. "Marco documental para el estudio de los colegios y bibliotecas jesuíticas en la España moderna”. Anuario de Historia de la Iglesia, 2011, 20, pp. 373-391.

12. Novísima Recopilación de las leyes de España, Libro VIII, Título III, Ley I, Tomo 4, Boletín Oficial del Estado, Madrid, 1805, p. 15.

13. Novísima Recopilación de las leyes de España, Libro VIII, Título I, pp. 1-11. 
la corte real tenían a su cargo habilitar a tales maestros, quienes pasaban luego a la órbita de contralor de la Hermandad de San Casiano. El Consejo de Castilla mantenía la facultad de expedir títulos, nombrar visitadores de escuelas o veedores, aunque a propuesta de la Hermandad. Sin embargo, si buscamos un concepto de educación se observa que en aquel momento la letra de la resolución real no incluía menciones sobre la finalidad de la instrucción, ni su relación con un plan general de la monarquía, ni tampoco una conceptualización al menos vaga sobre educación.

Un fenómeno cultural de la España de ese momento fue el auge de los estudios de latinidad o humanidades, motivado por combinación de factores religiosos, culturales, sociales y económicos, cuyo denominador común era la educación humanista como valor clave de un nuevo orden emergente ${ }^{14}$. La normativa da muestra de la preocupación por la calidad y el estado de ese tipo de instrucción, como surge de una disposición de 1747 por la cual Felipe VI ordenó que para los estudios de latinidad y otros previos a los de "Facultades Mayores", como los de gramática, el Consejo de Castilla propusiera cualquier medida que viese necesaria para mejorarlos al hallarse "sobradamente desatendidos" por la "falta de elegancia en el uso de este idioma, fuera de otros daños» debido a la abundancia de maestros ${ }^{15}$.

A partir de la letra de otros agregados legales se observa cómo la noción de ilustrar se incorpora dentro del corpus normativo de la monarquía, ampliando el concepto utilitarista de educación, asociado a la instrucción pública, mencionado respecto de años anteriores. En 1750 una incorporación de Fernando VI sobre la obligación de respetar las constituciones, gobierno y método de estudios del Real Seminario de Nobles de la Corte hizo alusión a otro objetivo común: estimular a la nobleza de los reinos a la instrucción más conveniente en los primeros años, para servir e «ilustrar a la Patria». Como medida práctica se ordenaba la impresión de las constituciones y métodos de estudio para que pudiesen servir de guía estricta a los encargados de los seminaristas; además de instrumentar certificaciones para los egresados con el objeto de otorgarles prioridad frente a empleos o ascensos ${ }^{16}$. Esta norma es importante porque habla de garantizar la validez y otorgar pruebas de calidad frente a terceros a los receptores de la educación pública. Para el Real Seminario de Nobles la monarquía contemplaba un concepto de educación amplio pero específico para quienes debían distinguirse por su nacimiento y estaban destinados a los principales cargos políticos. La instrucción contemplaba hasta aspectos gestuales y buenas maneras con adaptación a las tendencias europeas

14. Vergara Ciordia, Javier. "Humanidades y profesorado en los jesuitas de Pamplona (siglos XVI-XVIII)". Príncipe de Viana, Ejemplar dedicado a: VII Congreso General de Historia de Navarra, 2011, 2, año 72, 254, p. 449.

15. Novísima Recopilación de las leyes de España, Libro VIII, Título II, Ley II, p. 12.

16. Novísima Recopilación de las leyes de España, Libro VIII, Título III, Ley I, p. 16. 
de etiqueta y distinción ${ }^{17}$. Desde mediados del siglo XVIII el Seminario abrió sus puertas a estudiantes provenientes de sectores mercantiles acomodados, a la par de sufrir un proceso de militarización. No obstante, el mayor porcentaje de jóvenes pertenecían a la baja y media nobleza, a familias de administrativos de la Monarquía, de militares y oligarquías $\operatorname{locales}^{18}$. La importancia de la militarización en la educación de la juventud noble se reflejaba en el pedido de obras educativas y pedagógicas puntuales como la encomendada a Tadeo Lope y Aguilar para la enseñanza de las matemáticas como herramienta al servicio del arte de la guerra; educación que todo noble debía recibir con vistas «al bien general de cualquier monarquía ${ }^{19}$.

La normativa de la Novísima Recopilación da cuenta de una necesidad de educación con contralor y reordenamiento en función del bien público, además de esbozar una preocupación por el ocio, enemigo de la regeneración necesaria en la Monarquía, a pesar de que más allá de las novedades arriba detalladas continuaban vigentes normas del siglo XVI regulatorias de un amplio espectro de instituciones como los Colegios Mayores y las Universidades ${ }^{20}$. Es de mencionar que en la regeneración educativa buscada a partir del siglo XVIII, a pesar del espíritu de secularización, la colaboración de los obispos ilustrados fue de particular importancia ${ }^{21}$.

Paralelo al corpus normativo, el pensamiento ilustrado circulaba en esos años por diferentes canales de difusión e intercambio, con ediciones de diagnósticos, puntos de vista y recomendaciones prácticas ofrecidas al poder político. Una de las críticas principales acerca de los ilustrados españoles, que por muchos años transitó por círculos académicos, es que solo pudieron ofrecer un movimiento de ideas y reformas superficiales, cosméticas en comparación con las de sus pares franceses, ingleses, alemanes o de los Países Bajos; opiniones que no lograron constituir un cuerpo doctrinal relacionado con un sistema filosófico o científico específico y que, lejos de liberar, estuvieron al servicio de los poderes del Antiguo Régimen para reforzarlos. Sin embargo, interpretaciones recientes remarcaron que sin esas nuevas ideas culturales y sociopolíticas, con sus reformas y prácticas, es

17. Un ejemplo es la enseñanza de la danza desde su fundación en 1725 por Felipe V con reajuste a las maneras borbónicas francesas sobre fines del siglo XVIII. CAMPOO SCHELOTTO, Diana. "Danza y educación nobiliaria en el siglo XVIII. El método de la escuela de baile en el Real Seminario de Nobles de Madrid". Bilduma Ars: Revista del Departamento de Historia del Arte y Música de la Universidad del País Vasco, 2015, 5, pp. 158-173.

18. AndúJAR CASTIllo, Francisco. «El Seminario de Nobles de Madrid en el siglo XVIII. Un estudio social». Cuadernos de Historia Moderna. Anejos, 2004, 3, pp. 201-225.

19. LOPE Y AGUILAR, Tadeo. Curso de matemáticas para la enseñanza de los caballeros seminaristas del Real Seminario de Nobles de Madrid. Madrid: Imprenta Real, 1794, tomo 1, 708 pp.

20. Novísima Recopilación de las leyes de España, Libro VIII, Título III, IV y VI.

21. POY CASTRO, Raquel. "Regeneración educativa y cultural de la España moderna: reformas monárquicas en educación y el papel de los obispos de la ilustración en el siglo XVIII». Cuadernos Dieciochistas. Universidad de Salamanca, 2009, 10, p. 189. 
difícil poder interpretar la España de comienzos del siglo XIX y la gradual desintegración del imperio español entre 1810 y 1825; aun cuando la ilustración española haya sido esencialmente pragmática, utilitaria y aplicada, sin cuerpo doctrinal ${ }^{22}$. Con todo, el desarrollo del pensamiento ilustrado español, y en especial en torno al nuevo lenguaje de la Economía Política, fue fundamental en un periodo donde ésta fue motor de discusiones y reformas. La educación fue puesta en valor y revisión de distintas maneras como derivado de la agenda de temas que inquietaban el debate de cuestiones impulsadas desde la Economía Política.

El siglo XVIII, periodo entonces de "diálogos en Economía Política» como generador de lo político, permitió la migración de ideas hacia España en discusiones nutridas de lecturas foráneas -franceses o ingleses como Turgot, Forbonnais, Quesnay, Hume, Condillac o la ilustración napolitana como Genovesi, entre otrosdebatidas en nuevos espacios de sociabilidad y discusión ${ }^{23}$. Las ideas originales se vieron ampliamente enriquecidas y readaptadas al ámbito español ${ }^{24}$. Tampoco puede desestimarse la influencia del cameralismo germano, como fue el caso de las reflexiones de Francisco Romá y Rosell inspiradas en el pensamiento del barón Von Bielfeld, con alto contenido económico además de político ${ }^{25}$.

Por tanto, los intelectuales que reflexionaron sobre el tema educativo en la España dieciochesca estuvieron en su mayoría asociados a disquisiciones económicas propias y extranjeras. Resultan sin duda Gaspar Melchor de Jovellanos y Pedro Rodríguez de Campomanes los más difundidos, aunque muchos otros hicieron causa común en la temática: Francisco de Cabarrús, Cándido María Trigueros, Pascual Vallejo, Gregorio Mayans, Pablo de Olavide, fray Jerónimo Feijoo, León de Arroyal, José Moñino y Redondo (conde de Floridablanca), José Climent, Antonio Tavira o Francisco de Armañá. Un primer grupo de teóricos fue denominado

22. Astigarraga, Jesús. "Introduction». En Astigarraga, Jesús (ed.). The Spanish Enlightenment revisited. Oxford: Voltaire Foundation, University of Oxford, 2015, pp. 8-9.

23. Sobre la importancia de Lezioni di commercio del pensador napolitano: AsTIGARRAGA, Jesús y Usoz OTAL, Javier. "Del A. Genovesi napolitano de Carlo di Borbone al A. Genovesi español de Carlos III: la traducción española de las Lezioni di commercio de V. de Villava». Cuadernos de Historia del Derecho, Madrid, Universidad Complutense, 2008, 15, pp. 293-326; AstigarRaga Goenaga, Jesús. "Diálogo económico en la "otra" Europa. Las traducciones españolas de los economistas de la Ilustración napolitana (A. Genovesi, F. Galiani y G. Filangieri)». Cromohs: Cyber Review of Modern Historiography, $2004,9$.

24. Un ejemplo de la influencia napolitana fue el aporte de Ramón de Salas a fines del siglo XVIII, defensor del comercio -como garante para el aumento de la riqueza- desde un centro educativo como la Universidad de Salamanca y su Academia de Derecho Español de espíritu reformista, que significó una relectura crítica de las enseñanzas de Lezioni di comercio de Genovesi. AsTIGARRAGA Goenaga, Jesús. "Ramón de Salas y la difusión de la fisiocracia en España». Historia Agraria: Revista de Agricultura e Historia rural, 2010, 52, pp. 75-102.

25. Conocidos son los trabajos de Ernest Lluch. Véase: LLuCH, Ernest. «El cameralismo más allá del mundo germánico». Revista de Economía Aplicada, 1996, 10, 4, pp. 163-175. VON BIELFELD, Jakob. Institutions politiques. Chez Pierre Gosse Libraire de le prince de Stadhouder, tomos 1 y 2, 1760, pp. 789 pp. 
por Vicente Llombart Rosa la Generación de Uztáriz (1724-1760), con pensadores como Zabala y Auñón, Capillo, Ulloa, Santa Cruz de Marcenado, Argumosa o Gándara; nutrida de representantes del proyectismo y mercantilismo tardío; abocados a revisar el atraso económico español ${ }^{26}$.

En esa generación precursora, una de las obras de mayor difusión del pensamiento económico español de la primera mitad del siglo XVIII fue justamente la del mencionado Jerónimo Uztáriz, Theórica y práctica del comercio y la marina, aparecida en 1724: presentaba una reflexión en relación al fomento del comercio, la marina y las manufacturas con reformas impositivas y arancelarias, pero sin menciones respecto de la educación ${ }^{27}$. La única alusión sobre educación en términos vagos que efectúa el economista se observa en su presentación del ejemplo francés a partir de los opiniones del marqués de Vauban, al servicio de Luis XIV, en su libro El diezmo Real, donde preveía que una mejor educación (entre otras cualidades de los pueblos como la mejor alimentación, vestido, productividad laboral, etc.) se lograba con la disminución de la opresión a los súbditos, base para la riqueza de un rey y su reino, complementada con el trabajo, el comercio y los tributos. Fundamentos en suma de la conservación y crecimiento de la patria con el consiguiente interés de amor al beneficio público que debía promoverse ${ }^{28}$. Años más tarde, en 1732, Miguel de Zavala y Auñón, economista y funcionario de la Corona del primer grupo de pensadores, no se refería a la educación o instrucción en sus escritos ofrecidos a Felipe V con el objetivo de asegurar «el aumento del Real erario y conseguir la felicidad, mayor alivio, riqueza y abundancia de la Monarquía». Mencionaba pautas para mejor aprovechamiento de las tierras, el establecimiento de fábricas de todo tipo y el comercio con América por medio de Compañías Comerciales como ejes de regeneración ${ }^{29}$. Similar es el caso de uno de los trabajos de Álvaro Navia Osorio y Vigil, marqués de Santa Cruz de Marcenado, también aparecido en 1732. Formado en la Universidad de Oviedo, célebre

26. Llombart Rosa, Vicente. "Economía política y reforma en la Europa mediterránea del siglo XVIII: una perspectiva española». Mediterráneo Económico, Caja Rural Intermediterránea, Cajamar, 2006, 9, pp. 95-113. Sobre Mayans ante la imposibilidad de explayarnos aquí: Mestre SANCHís, Antonio. Don Gregorio Mayans y Siscar, entre la erudición y la política. Valencia: Institució Alfons el Magnanim, 1999, 393 pp. Asimismo: PESET ReIG, Mariano y José. Gregorio Mayans y la reforma universitaria: Idea del nuevo método que se puede practicar en la enseñanza de las universidades de España. Valencia: Ayuntamiento de Oliva, 1975, 363 pp.

27. Uztáriz ofrecía su análisis a Felipe V como caballero de la orden de Santiago, del Consejo de su Majestad y de la Real Junta de Comercio y Moneda, además de secretario del rey en el Consejo y Cámara de Indias para la pronta restauración de la Monarquía, beneficio universal y mayor fortaleza contra los émulos de la Real Corona. UzTÁriz, Gerónimo. Theórica y práctica de Comercio y de Marina. Madrid: Imprenta Antonio Sanz, 1757, 456 pp.

28. UzTÁriz, Gerónimo. Theórica, p. 24.

29. De Zavala y Auñón presentaba sus recomendaciones en su carácter de regidor de la ciudad de Badajoz, miembro del Consejo Real y superintendente general de la Pagaduría General de Juros y Mercedes. De Zavala y AuÑón, Miguel. Representación al rey nuestro señor Felipe $V$. Madrid: Imprenta Antonio Sanz, 1732, 180 pp. 
por sus reflexiones militares y considerado por Feijoo y Jovellanos como uno de los mejores estudiosos de los problemas económicos de España, además de diplomático en las cortes italiana y francesa, su rapsodia no ahonda en cuestiones educativas no obstante menciona la necesidad de dar educación como apoyo a uno de los dos puntos capitales de su propuesta como era "recoger tanta juventud perdida, tanta mujer y hombres vagos" para destruir la mendicidad, punto complementario del segundo consejo: «Establecer en modo perfecto, pero más pausado, todo género de Maniobras y Fábricas, dando labor a los preciosos y pingües frutos, en que con abierta mano dotó la naturaleza a estos Dominios ${ }^{30}$. Por último, iguales consideraciones pueden referirse para el trabajo de Bernardo de Ulloa publicado en 1740, quien con objetivos similares para la Corona no mencionó a la educación o instrucción al alertar sobre la necesidad de fomentar el comercio y las fabricaciones españolas ${ }^{31}$.

Como fuente escrita alternativa a la legislación y los escritos de los ilustrados circulaba en España en aquella época la edición de 1736 del Diccionario de la Lengua Castellana compilado por la Real Academia Española, institución de renovación cultural del siglo XVIII ${ }^{32}$. Resulta interesante observar el concepto de educación que incluía en sus páginas, con referencias a amaestrar y adoctrinar en los primeros años de vida. La reedición de 1783 incluyó aún las definiciones publicadas en 1736, ajustada a una edición de un único tomo para mayor practicidad de consulta: "Educación, s. f. La crianza, enseñanza y doctrina con que se educan los niños en sus primeros años. Educatio. Educado, da p. p. de educar. Educar, v. a. Criar, enseñar, amaestrar y dar doctrina á la juventud. Educare, instruere»33.

Más allá de la definición ceñida propia del diccionario y de las referencias generales citadas en los párrafos anteriores, una publicación de la prensa de esos años ofrecía un concepto interesante de educación. Entre otros canales de circulación impresa de ideas, como fueron los periódicos o revistas del siglo XVIII, se encontraba El Pensador, el semanario matritense editado por José Clavijo, impreso y distribuido en Madrid entre 1763 y $1767^{34}$. Cada número estaba dedicado a un

30. NAVIA OSORIO Y Vigil, Álvaro. Rapsodia económico política monárquica. Gijón: Universidad de Oviedo, 1984, pp. XVIII; XXIX.

31. DE UlLOA, Bernardo. Restablecimiento de las fábricas y comercio español. Madrid: Imprenta Antonio Marín, 1749, 267 pp.

32. Creada a imagen de la Academia Francesa en 1713 y con protección Real a partir de 1714 . Sobre significación, funciones de las Academias europeas y la elaboración del diccionario de la Real Academia española: FREIXAS ALÁs, Margarita. Las autoridades en el primer diccionario de la Academia Española. Tesis doctoral, director José Manuel Blecuas Perdices, Universidad Autónoma de Barcelona, 2003.

33. Real Academia Española. Diccionario de la Lengua Castellana. Madrid: Joaquín Ibarra Impresor de Cámara de S. M. y de la Real Academia, 1783, p. 399.

34. El Pensador se inserta en el conjunto de periódicos de crítica de costumbres, con opiniones teóricas que en tanto aspiraciones estuvieron lejos de concretarse en la realidad. LABRADOR HERRÁIz, 
pensamiento sobre un aspecto de la realidad social que se debatía en sus páginas ${ }^{35}$. En una edición sin fecha la publicación de unas cartas enviadas al editor daba cuenta de la preocupación de su autor por los riesgos de una educación particular deficiente en manos de ayos de mala formación, como él mismo había sufrido ${ }^{36}$. Debe notarse que la enseñanza doméstica era una variante en la educación de los niños en España desde el siglo XIV. Las familias con recursos podían contar con educadores que ingresaban a sus hogares como criados. Con el tiempo el modelo del colegio o aula palatina organizada por los Reyes Católicos para educación de los príncipes comenzó a ser imitado por las familias nobles. Los más adinerados llegaban a contratar a prestigiosos humanistas italianos para formar a sus hijos en griego y latín. Además del maestro, muchos contaban con un ayo, responsable del comportamiento social del alumno y de acompañarlo a la usanza de los antiguos griegos o romanos. Desde las reflexiones pedagógicas de Erasmo, Vives, Nebrija y otros se debatió sobre la conveniencia o no de la instrucción doméstica sobre la pública; lo habitual era que los jóvenes más acomodados comenzaran en casa, luego en la escuela y, antes de la Universidad, un pupilaje o internado para el estudio de gramática latina; aunque existieron distintas variantes según los ingresos de la familia en cuestión ${ }^{37}$. De todos modos, la escolarización siempre tendió a ser escasa y distaba de ser masiva, con alta incidencia de instrucción doméstica a los niños y jóvenes ${ }^{38}$.

El concepto de educación que aparece en la citada edición de El Pensador involucraba la virtud moral y el desarrollo del espíritu con una instrucción "racional»: la educación era un camino hacia las virtudes. El editor del periódico introducía la problemática alertando que la educación de los hombres, que incluía formar el corazón y el espíritu (las virtudes morales y la conducta de la vida), no era privativa de los ayos, sino también de los padres, que debían contribuir solos o acompañados al «bien de sus hijos, y al de la Nación, por medio de una educación racional y christiana». Un buen ayo debía guiar a su discípulo con capacidad de raciocinio desde la cuna, elevar su espíritu y corregir defectos de vanidad. Debían evitarse

Cármen y De PABlos RAmírez, Carlos. La educación en los papeles periódicos de la ilustración española. Madrid: Centro de Publicaciones del Ministerio de Educación y Ciencias, 1989, p. 229.

35. En un total de seis volúmenes contiene 86 pensamientos. Clavijo y Fajardo, Josef. El Pensador. Imprenta de Joaquín Ibarra, s. f., tomo 5, pp. 181-202.

36. Según el diccionario de lengua castellana de la época, "AYO, YA. s. m. y f. En lo antiguo era la persona encargada de la crianza de algún niño. Hoy se llama así el que está encargado de la educación. Pedagogus, custos, institutor pueri». ReAl ACADEMIA EsPaÑola. Diccionario de la Lengua Castellana, p. 133.

37. Delgado Criado, Buenaventura. "La educación institucional: la enseñanza doméstica». En Delgado Criado, Buenaventura (coord.). Historia de la educación en España y América (siglos XVIXVIII). Madrid: Fundación Santa María Buenaventura, 1993, vol. 2, pp. 170-174.

38. Losa SERrano, Pedro y CózAr Gutiérrez, Ramón. «Enseñanza y vida académica en la España Moderna. La secularización de la enseñanza en Albacete a partir de la expulsión de los jesuitas». Revista de Historia Moderna, Anales de la Universidad de Alicante, 2002, 20, p. 9. 
los ayos que pudiesen afectar la calidad de educación impartida -aun cuando el alumno no estuviese destinado a "subir a las Cathedras»- como el ejemplo presentado: un ayo proveniente "de las inmediaciones de cierta Universidad» pero tímido, interesado, ignorante, caprichoso, adulador y buscador en su discípulo de una vía para «acomodar a algunos parienticos y acudir a otras obras piadosas». Un personaje dotado de "fragilidades", lejos de ser un censor rígido de la conducta, y un maestro ilustrado celoso del bien. Ser buen ayo era promover el logro del bienestar individual y de la Nación: no descuidar la enseñanza de lenguas vivas, filosofía, música, poesía, dibujo, historia, matemáticas y aun el catecismo a favor de «unos malos principios de gramática y filosofía aristotélica». Por sobre todo ello el ayo debía proveer juicio, prudencia, discreción, afabilidad, "amistad ilustrada decente que depende de la razón y se mantiene con dignidad a pesar de una disciplina severa... sin mal humor, cólera ni aspereza». La carta da cuenta, en suma, de una preocupación por una educación integral, pero orientada a lecciones indirectas que a partir de defectos ajenos mostraran los propios y «tratándolo al discípulo como hombre, para que llegase a serlo" ${ }^{39}$.

De las fuentes escogidas entre las tantas disponibles para la primera mitad del siglo XVIII puede apreciarse que los textos con reflexiones propias del campo de la Economía Política presentaban como tema en común la creciente preocupación por la escasa actividad comercial a comienzos del siglo XVIII que impregnaba los debates que veían necesario el fomento del comercio, requisito de civilización ${ }^{40}$. En ellos, las alusiones a la educación son aún muy vagas y tornan difícil la posibilidad de delimitar un concepto al respecto. En la normativa se perfila un concepto de educación asociado a la instrucción pública, la utilidad, prevenciones sobre el ocio y el servicio a la patria; sin bien referido a sectores sociales en particular. En la prensa periódica seleccionada, si bien se trata de una publicación Ilustrada, se refiere a la educación no pública como formación para la virtud, sin menciones a conocimientos prácticos de tipo comercial salvo la matemática, pero como un ingrediente más con vistas a una formación general del espíritu.

\section{PROFUNDIZACIÓN DEL CAMPO SEMÁNTICO: EDUCACIÓN COMO BIEN SOCIAL Y PRINCIPIO ORDENADOR EN LA SEGUNDA MITAD DEL SIGLO XVIII}

En la segunda mitad del siglo bajo análisis una serie de sucesos generaron medidas políticas correctivas que impactaron directa o indirectamente en el plano educativo. Uno de los principales ámbitos de debate y reforma fue el religioso, donde destacó el control de la Iglesia desde la monarquía, proceso en que el Concordato de 1753 y la expulsión de los jesuitas fueron los puntos más evidentes de

39. Clavijo y Fajardo, Josef. El Pensador, pp. 203-218.

40. SÁnchez León, Pablo. "Ordenar la civilización: semántica del concepto de Policía en los orígenes de la Ilustración Española». Política y Sociedad, 2005, 42, 3, p. 143. 
su éxito ${ }^{41}$. El regalismo o gracia real llegó a influir en la integración o exclusión política del clero secular. En la primera mitad del siglo XVIII, el regalismo había acogido a la Ilustración católica y adoptó una política favorable a los jesuitas, con incremento de la autoridad política sobre la Iglesia católica ${ }^{42}$. En el reinado de Carlos III la Iglesia alcanzó carácter «regio» y ello no sólo favoreció la expulsión de los jesuitas en 1767, sino que significó la importación del galicanismo para convertir a los clérigos españoles en cuasi agentes reales ${ }^{43}$.

Las medidas de control y saneamiento se intensificaron tras la pragmática definitiva de abril de 1767 con la decisión de expulsión de los jesuitas, luego de urdirse un meticuloso plan de pesquisas y un silencioso proceso de preparación y deliberaciones ${ }^{44}$. En materia educativa se estableció la prohibición de enseñar en las universidades "la doctrina del regicidio y tiranicidio que se halla estampada y se lee en tantos autores, por ser destructiva del Estado, y de la pública tranquilidad». Los graduados, catedráticos y maestros de las universidades y Estudios del reino debían jurar la observancia de tal obligación, extendida además a prelados eclesiásticos en sus seminarios, a los superiores de las órdenes en sus estudios y a "las Justicias» ${ }^{45}$. Todas estas medidas fueron en parte el correlato de la inquietud desencadenada por el motín de Esquilache, la revuelta contra el principal ministro de Carlos III y sus medidas reformadoras, ocurrido el año anterior ${ }^{46}$. Por otra parte, se suprimieron en las Universidades y Estudios de la Monarquía las cátedras de la Escuela Jesuítica y el uso de los autores jesuitas en la enseñanza ${ }^{47}$; además de la prohibición política de doctrinas como las de Pedro de Calatayud, Suma Moral del hermano Busembaun o Enigma Theologicum de Álvaro Cienfuegos ${ }^{48}$. Ello se debió a las acusaciones de «desviacionismo doctrinal» que acompañaron al decreto de expulsión y condujeron

41. Véase EGIDo López, Teófanes. "Carlos III y la primera expulsión de los jesuitas». xx Siglos, 2000, vol. 11, 43, pp. 41-46.

42. ARTOla RENEDO, Andoni. "Reflexiones sobre la práctica del regalismo: gracia regia y alta carrera eclesiástica durante el reinado de Carlos III (1759-1788)». Hispania Sacra, julio-diciembre 2013, LXV, Extra II, pp. 253-282.

43. SMIDT, Andrea. "Bourbon regalism and the importation of gallicanism: the political path for a state religion in Eighteenth-Century Spain". Anuario de Historia de la Iglesia, 2010, 19, pp. 25-53.

44. Cortés PeÑa, Antonio Luis. "Algunos ejemplos del control gubernamental sobre los jesuitas tras la expulsión». En MESTRE SANCHís, Antonio y GIMÉNEZ LóPEZ, Enrique (coords.). Disidencias y exilios en la España Moderna, 1997, vol. 2, p. 692.

45. Novísima Recopilación de las leyes de España, Libro VIII, Título IV, Ley III, p. 23.

46. Una interpretación reciente del contexto social en torno al motín puede verse en SÁNCHEZ LEÓN, Pablo. "Conceiving the multitude: Eighteenth-Century popular riots and the modern language of social disorder». IRSH. International Review of social History. Cambridge: Cambridge University Press, 2011, 56, issue 3, pp. 511-533.

47. Respecto de la situación intelectual de los jesuitas luego de la expulsión de 1767 resulta interesante el ejemplo trabajado por Astorgano ABAJo, Antonio. "Floridablanca y el jesuita Hervás y Panduro, una relación respetuosa». Res Pública. Universidad de Murcia: Facultad de Filosofía, 2009, 22, pp. 325-362.

48. Novísima Recopilación de las leyes de España, Libro VIII, Título IV, Ley IV, p. 23. 
a la materialización de medidas concretas ${ }^{49}$. El debate religioso se daba también en el seno de la propia Iglesia en busca de redefiniciones doctrinales, devocionales y educativas; atravesaba a la vez a los círculos Ilustrados, donde figuras como Jovellanos y otros compartían espacios con pensadores religiosos. Tal fue el caso del célebre salón liderado por la condesa de Montijo, círculo con conexiones jansenistas o parajansenistas que planteó, entre otras cuestiones, debates sobre una educación religiosa de nuevo corte con eje en la correspondencia entre moral y utilidad cristianas $^{50}$.

En ese mismo contexto continuaba la aparición de reflexiones económicopolíticas donde el comercio ganaba terreno, reflejo del debate iniciado a partir de la entronización de Carlos III, en las que la preocupación por la situación del comercio abarcaba todos los confines de la Monarquía ${ }^{51}$. A la mencionada primera generación de pensadores siguió la Generación de Campomanes entre 1760 y 1780 -Campomanes, Olavide, Ward, Arriquibar, Romá y Rosell, Ramos y Dánvila Villarrasa-, que marcó el auge inicial de la economía política española; con diagnósticos sobre el atraso y legitimación de políticas económicas reformadoras que podían influir sobre el estancamiento. Todo ello contemporáneo al aumento en la intensidad de la circulación internacional de obras como las de Petty, Child, Davenant, Mirabeau, Melon, Catillon, Turgot o la Encyclopédie.

A ella seguiría la Generación Jovellanos junto a Foronda, Cabarrús, Alonso Ortiz y Alcalá Galiano, entre otros, nutridos por el pensamiento del mencionado Genovesi, Filangieri, Necker, Hume, Quesnay o Adam Smith². Ellos serían característicos de la Ilustración tardía española y la consolidación de la economía política como «ciencia del gobierno" y del ciudadano al servicio de la «felicidad pública» ${ }^{33}$. El concepto de felicidad era de mención o análisis frecuente en la mayor parte de los escritos e incluso en los documentos oficiales. La felicidad sirvió de marco para justificar decisiones políticas e inspiró a buena parte de los pensadores promotores de algunas de esas medidas: Bernardo Ward, contemporáneo de Campomanes,

49. Mestre SAnchís, Antonio. "Pugnas por el control de la Universidad después de la expulsión de los jesuitas". Revista de Historia Moderna: Anales de la Universidad de Alicante, 1988-90, 8-9, pp. 91-118.

50. Entre la vasta bibliografía: Froesch'LÉ-CHOPARD, Marie-Hélène. "Les "Nouvelles ecclésiastiques" et les Lumières (année 1750)». Dix-huitième siècle: revue annuelle de la Societé Française d'Étude du Dix Huitieme Siecle, 2002, 34, p. 82; 77-89. Como fuente entre otras: LE TournEAux, Nicolás. Instructions chretiens sur le sacrement de marriage et les céremonies avec lesquelles l'Église l'administre. Paris: D. Mariette, Nouvelle Édition, 1727.

51. Astigarraga Goenaga, Jesús. «Las Reflexiones (1761) de Simón de Aragorri y la reforma del comercio atlántico español». Revista de Indias, 2013, vol. 73, 259, pp. 759-788.

52. LlOMBART Rosa, Vicente. Economía política y reforma, pp. 95-114.

53. OCAMPo SuÁrez VAldés. Joaquín. "Jovellanos; Ilustración, economía y felicidad pública». Cuadernos Dieciochistas. Ediciones Universidad de Salamanca, 2010, 11, pp. 93-117; OCAMPO SuÁREZ VALDÉs, Joaquín. «Jovellanos: la reconstrucción de un clásico». Estudios de Economía Aplicada, 2014, 1, vol. 32, pp. 83-110. 
en 1761 se refirió al concepto de felicidad más de veinticuatro veces en su trabajo Proyecto Económico y el doble de veces al concepto de policía como condición coadyuvante para alcanzarla ${ }^{54}$.

Un concepto importante de educación del periodo a partir de Cándido María Trigueros es el de educación como bien social y objeto de política pública que presentó como académico y pedagogo en 1768 ante la Real Academia Sevillana de Buenas Letras en su disertación sobre un nuevo método de estudios ${ }^{55}$. Planteaba la necesidad de una educación pública bajo tutela del rey que le diera carácter legal y la impusiera en todos sus dominios. La educación no debía ser objeto de la beneficencia, sino de la política "por la utilidad que de ella resulta a los particulares y a la República. La educación es un bien social y como tal debe ser cuidado por los políticos». La educación como cultura de los talentos de los jóvenes «que pide tan de veras el interés general de una nación bien gobernada, debe consistir en facilitar todos los medios para la consecución del fin y vencer todas las dificultades y estorbos que ofrece la flaqueza y debilidad de los sujetos en que debe emplearse». Facilitar medios y vencer dificultades debía ser la premisa de un Gobierno ilustrado con aplicación del proyecto desde las primeras letras ${ }^{56}$. Así veía Trigueros a la educación en tanto modelación del talento en los jóvenes. Trigueros resaltaba la noción de utilidad, de política pública y generalidad desde las primeras letras presentando un concepto que es a la vez político para la acción concreta.

Francisco Romá y Rosell, convencido de la utilidad de la "ciencia del Gobierno» para mantener los grandes imperios y elevar a los pequeños, presentó también en 1768 su visión de los pilares en los que descansaba la felicidad de España y la forma de potenciarla. El escrito eleva al comercio interior y exterior, junto a la población, agricultura y manufacturas, como pilares del restablecimiento de una Monarquía junto a la educación tendiente a inspirar «nobles sentimientos a la juventud que aspire a los empleos ${ }^{57}$. Su concepto de educación pública incluía a los hospicios como reservorio de jóvenes a quienes educar en favor del reino y cualquier desorden era positivo para que un buen gobierno pudiera sacar ventajas ${ }^{58}$. El

54. WARD, Bernardo. Proyecto Económico en que se proponen varias providencias, dirigidas á promover los intereses de España, con los medios y fondos necesarios para su planificación. Madrid: Imprenta Ibarra e hijos, 1787, $400 \mathrm{pp}$.

55. Real Academia Sevillana de Buenas Letras. Sevilla: Imprenta Josep Padrino y Solís, 1768, tomo 1, p. CIX.

56. Aguilar y PiÑAl, Francisco. El académico Cándido María Trigueros (1736-1798). Real Academia de la Historia, 2001, p. 189.

57. Romá y Rosell, Francisco. Las señales de la felicidad de España y los medios de hacerlas eficaces. Madrid: Imprenta Muñoz del Valle, 1768, p. 3

58. Su hipótesis planteaba como causa principal de la decadencia de la Monarquía española el descubrimiento de las minas, con el consiguiente alza de precios de todos los géneros y la introducción de manufacturas extranjeras de bajo precio, destructoras de las fábricas nacionales y en consecuencia la agricultura, el comercio y la población; bases de las riquezas de una monarquía. La población 
abandono de niños en hospicios y casas de huérfanos era una oportunidad para el Estado de educar a multitudes de niños para ser empleados por el Gobierno y las artes. Se requería entrenamiento de directores a cargo y una misión detallada para el funcionario promotor del bien público y de la economía del Estado encargado de fiscalizar y promover el funcionamiento de los hospicios ${ }^{59}$.

Su concepto de educación pública aludía también a la virtud y a la necesidad de promoverla para evitar la decadencia y ruina de las monarquías. La educación debía poner freno a los desvíos hacia una sana política y evitar los defectos nacionales: "Las costumbres que forman parte del espíritu de una Nación, son un habito nacido del exemplo, siempre emendables, coopere poco, o mucho el clima a introducirlas y a mantenerlas, y el más digno objeto de la educación pública». Debía educarse en las letras pero también en las costumbres para lograr el mayor número de personas virtuosas. Con una buena educación pública, el orden se restablecía naturalmente ${ }^{60}$.

En conexión con la Economía Política, el lujo, problemática central de la Ilustración, es un concepto paralelo que trabaja en su propuesta. Junto al comercio libre como pilar de expansión, el lujo positivo contenido dentro de ciertos límites era necesario en España para restablecerla y preservarla de la ruina ${ }^{61}$. Un tema presente en toda España, en escritos intelectuales y en la prensa de finales del siglo XVIII, que combinaba la publicación de acaloradas defensas del comercio con rotundas críticas al lujo y la moda ${ }^{62}$. Vemos entonces en Romá y Rosell un concepto de educación en armonía con la promoción del comercio para el crecimiento; asociado al lujo como objetivo y como parte de una política pública inclusiva de toda la población. Estas nociones dialogan a su vez con el concepto de civilización, no exento de ambivalencias en su definición, vinculado a cuestiones económicas, definición de roles sociales o comportamientos esperados para hombres y mujeres, con claro correlato en discusiones en materia educativa ${ }^{63}$.

representaba un recurso esencial para el progreso, con especial énfasis en las políticas de matrimonios. Romá y Rosell, Francisco. Las señales de la felicidad, p. 8.

59. Romá y Rosell, Francisco. Las señales de la felicidad, pp. 27-37.

60. En la restauración de monarquías, se debía poner cuidado en conocer plenamente la Nación para aprovechar sus virtudes y enmendar defectos, aunque reconocía que no era obra a concretar en el corto plazo. Romá y Rosell, Francisco. Las señales de la felicidad, pp. 284-290.

61. Un lujo negativo o perjudicial, aquel que procedía de entendimiento desarreglado y de corazón corrompido. Al lujo positivo o útil a cualquier Nación lo definía como nacido de un deseo, de un ansia "de tener la casa bien alajada, de presentarse bien vestido, de igualar el tren al de una clase inmediatamente superior, aplicando para conseguirlo la industria, y las fuerzas». Era el remedio más rápido en un país apto para población numerosa, decaído y despoblado por causas accidentales para dar ocupación a las familias: contribuía al consumo, con efecto expansivo sobre las manufacturas y el comercio activo. Romá y Rosell, Francisco. Las señales de la felicidad, pp. 42-59.

62. PÉREZ ABril, Dora. "Lujo, moda y modernidad en la prensa española del siglo XVIII». Res Publica: Revista de Filosofía Política, 2009, 22, pp. 249-256.

63. Bolufer Peruga, Mónica. «El arte de las costumbres: una mirada sobre el debate de la civilidad en España a finales del siglo XVIII". Res Publica: Revista de Filosofía Política, 2009, 22, pp. 195-224. 
Si observamos las disposiciones de la Corona en esos años surge que las medidas ordenadas referían al poder de policía, a la censura o al regicidio y no estrictamente al concepto de educación, aunque estuviese relacionado con cuestiones educativas. Así, por ejemplo, se creó en 1770 el cargo de censor regio en las universidades para preservar las regalías de la Corona en las cuestiones debatidas en ellas, con prohibición de enseñanzas o discusiones en contravención que los censores debían evitar con revisión de todas las conclusiones emanadas de los centros de estudios ${ }^{64}$. Ese año también se restablecieron los Reales Estudios del Colegio Imperial de la Corte por voluntad del rey, quien después de expulsados los jesuitas manifestó su interés de conservar no solo las fundaciones pías de sus iglesias, sino además los citados Reales Estudios que estuvieron a cargo de dichos regulares a partir de su creación en 1629. Se reestablecían sus estudios comenzando por los de latinidad, poesía, retórica, griego, lenguas orientales, matemáticas, filosofía, derecho natural y disciplina eclesiástica ${ }^{65}$.

Una segunda medida de reacomodamiento fue el arreglo de los seis Colegios Mayores de Salamanca, Valladolid y Alcalá a sus primitivas constituciones en 1771; con estricta prohibición de juegos y control de la residencia de los estudiantes por la decadencia en que se hallaban, en "gran perjuicio de la pública enseñanza y del Estado". Se esperaba que bajo la tutela real los estudiantes lograsen el verdadero camino de la virtud y letras para los empleos correspondientes en beneficio del Estado y de la Patria "66. El deterioro de los colegios fue evidente entre 1730 y 1750. El memorial presentado al rey por Francisco Pérez Bayer, Libertad de la literatura española, denunciando el abuso de los colegiales habría sido el detonante de la inspección con posteriores reformas a partir de 1771 en las que Carlos III decidió la adecuación a las constituciones primitivas. La reforma de Carlos III significó el cambio más importante en la trayectoria de dominio político que los colegiales ejercieron desde el siglo $\mathrm{XV}^{67}$.

Otra medida de ese año fue la prohibición de educación conjunta de niños y niñas, al tiempo que se reglamentaron los contenidos a impartir. Se debían reemplazar los libros de fábulas frías, historias mal formadas o «devociones indiscretas sin lenguaje puro ni máximas sólidas con las que se deprava el gusto de

Sobre cuestiones de género, educación y roles sociales, entre otros: López Cordón CorTEzo, María Victoria. "Los estudios históricos sobre las mujeres en la Edad Moderna: estado de la cuestión». Revista de Historiografía, 2015, 22, pp. 147-181; Bolufer Peruga, Mónica; Blutrach, Carolina y Gomis, Juan (eds.). Educar los sentimientos y las costumbres. Una mirada desde la historia. Zaragoza: Institución Fernando el Católico, 2014; Bolufer Peruga, Mónica. «En torno a la sensibilidad dieciochesca: discursos, prácticas, paradojas». En CANDAU CHACÓN, María Luisa (coord.). Las mujeres y las emociones en Europa y América: siglos XVII-XIX, 2016, pp. 29-58.

64. Novísima Recopilación de las leyes de España, Libro VIII, Título V, Ley III, p. 30.

65. Novísima Recopilación de las leyes de España, Libro VIII, Título II, Ley III, p. 13.

66. Novísima Recopilación de las leyes de España, Libro VIII, Título III, Ley VI, p. 17.

67. Carabias Torres, Ana María. "Evolución histórica del Colegio Mayor del siglo XIV al XXI». Redex, Revista de Educación de Extremadura, 2013, 5, p. 70. 
REGENERACIÓN, ECONOMÍA POLÍTICA Y EDUCACIÓN EN LA MONARQUÍA ESPAÑOLA DEL SIGLO XVIII...

los niños» para evitar el acostumbramiento a locuciones impropias, credulidades nocivas y "á muchos vicios transcendentales á toda la vida" ${ }^{68}$. Esta última norma puede considerarse cercana a los proyectos mencionados que promovían la virtud y saneamiento de las costumbres.

El corpus normativo analizado en este apartado contiene básicamente disposiciones de control en el ámbito educativo emanadas del contexto de inestabilidad luego del motín de Esquilache y la expulsión de los jesuitas: tendían a evitar el tiranicidio, el regicidio, desterrar la influencia jesuita, el ocio, la vagancia y el vicio. No referían a un concepto de educación ni tampoco relaciones con cuestiones de política económica. En las reflexiones ilustradas, por el contrario, se refleja la preocupación por el deterioro del comercio; la educación como equivalente a bien social y por ende objeto de política pública, de carácter legal, útil y obligatoria en toda la Monarquía, sustraída de la beneficencia y en correspondencia con el concepto de virtud.

\section{EDUCACIÓN, COMERCIO Y MANUFACTURAS: UTILITARISMO Y POLICÍA}

Corresponde mencionar, si bien no resulta posible abordar en detalle todas las vinculaciones entre educación y Economía Política durante el siglo XVIII español, la cercanía entre ambas para la promoción de enseñanzas teórico-prácticas; conexión donde la influencia de la Economía Política francesa permitió la introducción de textos sobre la ciencia del comercio de autores de otros orígenes. Dentro de ella, la vigencia de ideas del círculo de Gournay a partir de 1759 (advenimiento de Carlos III) o las del ginebrino Jacques Necker entre 1780-1800 fueron algunas de las más destacadas ${ }^{69}$.

Las obras de formato alfabético como diccionarios o enciclopedias fueron típicas del siglo XVIII europeo y se extendieron al campo de la Economía Política. Prueba de esto fue la aparición de manuales docentes, para comerciantes, revistas y publicaciones periódicas con vistas a popularizar los conocimientos económicos. Los diccionarios de comercio tuvieron amplia difusión, como en Inglaterra el Trade and commerce entre 1751 y 1755; o en Francia el Diccionaire universal de commerce (1723-1730) de los Savary. El diccionario francés fue de amplia difusión en España mucho antes de 1730, desde Feijoó y Mayans, si bien la generación de economistas de Felipe $\mathrm{V}$ fue la que comenzó a darle un uso intensivo hasta

68. Novísima Recopilación de las leyes de España, Libro VIII, Título 1, Ley II, p. 2.

69. Astigarraga Goenaga, Jesús y Zabalza Arbizu, Juan. "Francisco Crawinkel, plagiario de Richard Cantillon (1760-1763): una "nueva política” para la Monarquía española". Mélanges de la Casa de Velázquez, 2014, 44, 2, pp. 225-247; AstigarRaGA GoenaGA, Jesús. "Necker y Jovellanos: un "área neckeriana" en el Informe de Ley Agraria”. Revista de Historia Económica -Journal of Iberian and Latin American Economic History, 1998, 2, pp. 559-570; AstigarRaga GoENAGA, Jesús. "Necker en España, 1780-1800». Revista de Economía Aplicada, 2000, vol. 8, 23, pp. 119-144. 
convertirlo, junto al Dictionnaire de L. Moreri, en la principal fuente enciclopédica de información económica en los dos primeros tercios del siglo XVIII español. Desde los primeros economistas españoles del Setecientos se apoyó la realización de diccionarios lexicográficos, como el Diccionario de Autoridades de la Real Academia, que exigía contar con diccionarios versados sobre el «espíritu de comercion, muestra de la necesidad de acomodar a la cultura comercial española usos mercantiles y medidas legislativas que ya habían mostrado su eficacia en las potencias comerciales más desarrolladas. En este sentido, este primer éxito en España del Dictionnaire de los Savary es inseparable del de la economía colbertista en su conjunto ${ }^{70}$.

El apoyo a una educación práctica asociada a las necesidades de expandir la economía política puede hallarse también en el periodismo económico español del siglo XVIII; situación que evidencia la demanda de información asociada a la expansión del capital comercial. Ejemplos de tales publicaciones fueron los Discursos Mercuriales, editados en 1752 en defensa del comercio; Diario noticiosoerudito comercial, Público y Económico, desde 1758; El correo general histórico, literario y económico, en 1763; Semanario Económico, en 1765, o Memorias Instructivas, de 1778. Todos ellos buscaban informar sobre actividades marítimo mercantiles o difundir enseñanzas analíticas y doctrinales; estas últimas en general auspiciadas por instituciones como los Consulados, las Juntas de Comercio o las Sociedades Económicas de Amigos del País ${ }^{71}$.

Fue desde la segunda mitad del siglo XVIII que las traducciones de obras económico-políticas aumentaron su circulación por Europa; y en España fueron impulsadas por actores políticos como Aranda, Campomanes, Lerena, Floridablanca o Godoy. Ello formó parte de la profundización en España de una cultura económica que veía florecer la publicación de libros, revistas, diccionarios, la fundación de sociedades y cátedras universitarias específicas que contribuyeron a la consolidación de la Economía Política en la esfera pública ${ }^{72}$.

La vinculación entre educación y Economía Política manifestada en la aparición de nuevas materias en el ámbito académico y universitario está asociada a la visión de que las reformas borbónicas en educación superior fueron un tanto débiles, aunque se reconoce que existió a partir de 1765 un esfuerzo de modernización notable. Ejemplo de ello, la creación de las primeras cátedras de Derecho

70. Astigarraga Goenaga, Jesús y Zabalza Arbizu, Juan. "Economía política” y "Comercio" en los diccionarios y la literatura enciclopédica española del siglo XVII». Bulletin hispanique, 2009 , vol. 111, 2, pp. 387-427; Astigarraga Goenaga, Jesús y Zabalza Arbizu, Juan. "Los diccionarios de Comercio y Economía en el siglo XVIII español». Revista de Historia Industrial, 2007, 35, pp. 13-46.

71. OCAMPO SuÁrEZ-VAldÉs, Joaquín. «El Semanario Económico (1765-1767): a la Ilustración por la utilidad». El Argonauta Español, 2013, 10, pp. 4-5.

72. Astigarraga Goenaga, Jesús. "La finalidad política de las traducciones económicas. George Grenville en la Ilustración española». Historia y Política: Ideas, Procesos y Movimientos Sociales, 27, 2012, pp. 169-201. 
Público y Economía Política que no lograron buena parte de sus propósitos, pero fueron, junto a la Filosofía Moral, los emblemas ilustrados para la modernización de las ciencias sociales. Además de los ambientes universitarios, las Sociedades Económicas desplegaron actividad docente con empeño como la Sociedad Bascongada con su Seminario de Bergara o las Matritense y Segoviana. Referencia adicional es la Sociedad Aragonesa, creadora en 1784 de la cátedra de Economía Civil y Comercio entre otras, sumadas a escuelas de enseñanza de oficios que generaron una experiencia docente pionera en la España de su tiempo ${ }^{73}$.

Los conocimientos de comercio y economía con carácter práctico se difundieron en espacios variados como el caso de la difusión en Cataluña de conocimientos de ese tipo para la burocracia y el público en general analizado por Pere Molas Ribalta ${ }^{74}$. Y aun siendo el objetivo primario la difusión de conocimientos y doctrinas económicas, otras preocupaciones atravesaban la agenda temática como el rol de los sexos, presente tangencialmente en las Sociedades Económicas de Amigos del País ${ }^{75}$.

Ejemplo de una educación con finalidad concreta en el campo de la Economía Política es el texto clásico de Campomanes Discurso sobre la educación popular de los artesanos y su fomento, de 1775, de cita ineludible. A pesar de ser una fuente harto trabajada en la historiografía merece recordarse por ser una de las más significativas de la Ilustración española para promover la dignidad social de los sectores populares junto a una concepción de la enseñanza como factor de progreso social; en un proyecto de continuidad reformista sin ruptura con el pasado y sus tradiciones que se ha ubicado entre un pragmatismo utópico y un conservadurismo social ${ }^{76}$.

De manera clara, decadencia, regeneración, economía y educación se enlazan en el texto. El párrafo introductorio asimila la educación con la "norma" necesaria para vivir en cualquier sociedad ordenada. La educación debía diferenciarse según las clases de la misma sociedad y ser impartida desde la niñez -lectura, escritura y aritmética- para evitar la ociosidad; con principios comunes a todos los individuos de la república que combinaran religión y orden público ${ }^{77}$. Campomanes relacionaba educación, deterioro de los oficios y decadencia económica para explicar

73. Astigarraga, Jesús y Usoz OTAL, Javier. «El pensamiento político ilustrado y las cátedras de la sociedad económica aragonesan. Anuario de Historia del Derecho Español, 2008-2009, 78-79, pp. 423-446.

74. Molas Ribalta, Pere. "Tres textos econòmics sobre la Catalunya Il-lustrada». Pedralbes: Revista d'bistoria moderna, 1987, 7, pp. 147-162.

75. Bolufer Peruga, Mónica. «Femmes et hommes dans la société idéale: les Sociétés économiques des amis du pays dans l'Espagne des Lumières". Dixhuitième siècle: revue annuelle de la Societé Française d'Étude du Dix Huitieme Siecle, 2011, 43, pp. 487-504.

76. De Pedro Robles, Antonio. «Pedro Rodríguez de Campomanes y el "Discurso sobre la Educación Popular"”. Cuadernos Dieciochistas. Universidad de Salamanca, 2006, 7, p. 198.

77. Rodríguez de Campomanes, Pedro. Discurso sobre la educación popular de los artesanos y su fomento. Madrid: Imprenta de Antonio Sancho, 1775, pp. 1-2. 
el estancamiento de la Monarquía ${ }^{78}$. Introduce al comercio como el principal de los medios disponibles para facilitar el consumo de los "géneros producidos en el Reyno" a la vez de fomentar el trabajo de todos los súbditos en ocupación honesta y útil ${ }^{79}$. La educación debía ser complemento de la decisión política de fomentar determinadas artes y oficios convenientes para España. El "gobierno público» era el obligado a proporcionar adelantos en beneficio de la instrucción sin distinción entre naturales y extranjeros ${ }^{80}$. Los conceptos de educación y policía eran base de la prosperidad, controlando el aseo y vestido de los jóvenes, la enseñanza práctica de los oficios, subordinación de discípulos a sus maestros, rigor y justificación de los exámenes con premios para lograr ciudadanos industriosos ${ }^{81}$. La educación debía ser extensiva a las mujeres para que inspirasen en sus hijos y maridos conductas de laboriosidad. Consideraba un «error político» no considerar a las mujeres para las artes y los oficios ${ }^{82}$. La preocupación de Campomanes por la educación de las mujeres se basaba en su certeza de que el atraso de la industria popular no respondía a la pereza de los españoles, sino a la inactividad femenina por cuestiones de mentalidad y al segundo plano ocupado por las sociedades económicas de amigos del país ${ }^{83}$.

Campomanes impulsó durante la mayor parte de su carrera política el establecimiento de instituciones económicas en España, intención concretada entre

78. El reinado de Felipe III fue en su opinión el último de florecimiento de las manufacturas y de la población, y la caída de la población consecuencia del proceso de cese de las manufacturas; si bien el siglo XVIII conoció los avances en la eliminación de muchos de los obstáculos políticos causantes de tal situación, veía necesaria la puesta en "utilidad común» de los oficios, claves en el proceso de fortalecimiento. Rodríguez de CAMPomanes, Pedro. Discurso sobre la educación popular, p. 16.

79. La premisa era fomentar en habitantes el trabajo en ocupación «honesta y últil» con miras a la perfección y esmero. Rodríguez de CAmpomanes, Pedro. Discurso sobre la educación popular, pp. $17-20$.

80. En este último punto, acusaba a las comedias por elogiar la ociosidad; como Lope de Vega, quien tituló una de sus comedias La pobreza no es vileza, dando carácter positivo a la pobreza voluntaria que Campomanes menciona como deshonra y delito. Tal conducta estereotipada llevaba al «vulgo o pueblo indocto" a preferir el ocio descansado a la fatiga de un oficio penoso y difícil de aprender. RODRíguez de CAmpomanes, Pedro. Discurso sobre la educación popular, pp. 11-18.

81. Su principal objetivo era remarcar la importancia del poder de policía sobre los artesanos y su actualización en materia de legislación municipal. El segundo era insistir en la educación (desde las obligaciones de aseo y limpieza) descuidadas por padres y maestros en los niños; asunto que no podía pasar indiferente atento a que un tercio de la población de "la nación española" se veía afectada por esta situación. Rodríguez de Campomanes, Pedro. Discurso sobre la educación popular, p. 21.

82. El ejemplo de las mujeres de provincias marítimas de Galicia, Asturias, Montaña, Vizcaya y Guipuzcoa, dedicadas a la pesca de mar en embarcaciones, era loable frente a las habitantes de provincias interiores o del sur quienes por lo común vivían en un "profundo descanso, y con miseria: compañera inseparable de la ociosidad». Rodríguez de CAmpomanes, Pedro. Discurso sobre la educación popular, pp. 358-359.

83. Peñalver Gutrao, Víctor y Riaza Díaz, Paola. "Campomanes y su discurso sobre el fomento de la industria popular». Cartaphilus: Revista de Investigación y Crítica Estética, 2010, 7-8, p. 219. 
1774 y 1775 con el comienzo de su proliferación ${ }^{84}$. Sus proyectos gestados durante treinta años influyeron en las reformas económicas implementadas en la Monarquía española a mediados de la década de $1770^{85}$.

Las Sociedades Económicas fueron fundamentales en la difusión de conocimientos que interesaban a la Economía Política tanto doctrinales como prácticos ${ }^{86}$. En 1776 una memoria presentaba la defensa de uno de sus miembros para la implantación en España de enseñanzas sobre la teoría general del comercio ${ }^{87}$. También reflejaron la preocupación por otro aspecto relacionado con la educación: el establecimiento y mantenimiento de hospicios para pobres y desamparados. Respecto de tales instituciones, donde las más antiguas eran los hospicios de Madrid y las Casas de misericordia de Zaragoza y Valencia, se aludía en una ocasión que aunque útiles para la enseñanza en defecto de otros establecimientos y para intimidar a "cierta clase de gentes que repugnan el trabajo, y quieren vivir en la ociosidad y olgazanería á expensas de los demás»; eran inútiles para la educación y gravosos para el Estado. Resultaba una educación desventajosa para el Estado porque aun arreglada a los principios cristianos y piadosos no promovía talentos ni preparaba para la vida, no proveían una verdadera ocupación para ejercer con libertad y de mayor utilidad para el Estado y los pobres. La educación de los pobres debía establecerse sobre otras reglas y principios, con la mayor atención del Gobierno; con miras a una educación laboriosa que destruyera lentamente la pobreza; con ocupación constante, continua y universal; con atención al clima y proporciones de cada provincia. Se reconocía la utilidad del auxilio de la Iglesia

84. Para ilustrar sobre su consideración, fundaciones y funcionamiento: ENCISO RECIO, Luis Miguel. Las sociedades económicas vistas por los ilustrados. Las opiniones de Campomanes y Jovellanos. Torre de los Lujanes: Boletín de la Real Sociedad Económica Matritense de Amigos del País, 2010, 67, ENCiso Recio, Luis Miguel. "La génesis de la Sociedad Económica de Amigos del País de Zamora». Estudis: Revista de Historia Moderna, 1988, 14, pp. 219-244.

85. Astigarraga, Jesús. "Economic societies and the politicization of the Spanish Enlightenment». En Astigarraga, Jesús (ed.). The Spanish Enlightenment revisited, p. 72.

86. Las memorias de la Real Sociedad Económica de Madrid exponían temas de amplia variedad: argumentos en defensa de la libertad de comercio, de las Escuelas Patrióticas, estadísticas sobre el ingreso de fanegas de trigo y cebada a España, instrucciones sobre el uso de insumos y tecnología agrícola, opiniones sobre Compañías perjudiciales al comercio, causas del deterioro en la comercialización de ciertos productos, enseñanzas puntuales a impartir en las escuelas erigidas en fábricas, instrucciones sobre la comercialización de granos, cómo organizar distintos aprendizajes o examinar a los aprendices, entre muchos otros temas para la industria, los oficios, el comercio o la agricultura. Memorias de la Sociedad Económica de Madrid, Memoria sobre el recogimiento y ocupación de los pobres presentado en Junta General Marzo 1778. Madrid: Antonio de Sancha Impresor de la Sociedad, tomos 1-5, 1778-1795.

87. Astigarraga Goenaga, Jesús. "André Morellet y la enseñanza de la economía en la ilustración española. La "Memoria sobre la utilidad del establecimiento de una escuela de comercio"”. Cuadernos de Historia Moderna, 2010, 35, pp. 143-173. 
en la búsqueda de la nueva pedagogía ${ }^{88}$. Las Sociedades fueron importantes para el desarrollo de las Escuelas Patrióticas, de impacto educativo y a la vez económico como el caso del Montepío de Hilazas que en 1787 pasó a cargo de la Junta de Damas de la Sociedad Matritense y abastecía de materias primas a las Escuelas, previa localización, transporte, limpieza y almacenamiento a cargo de casi 800 trabajadoras en el Montepío; lo mismo que la Real Inclusa de Madrid o la educación de las presas en las cárceles reorganizadas con fines educativos y laborales para beneficio de la Monarquía ${ }^{89}$.

Dentro del plan de reformas generales, las Sociedades Económicas de Amigos del País debían convertirse en agentes de una nueva política cuyo fin no era el poder dinástico, sino la felicidad pública con eje en el espíritu del comercio y que precisaba de la educación pública para transformar la mentalidad u opinión de la sociedad $^{90}$. Se bregaba por un concepto de educación en sentido amplio con formación en el oficio, pero también como ciudadano útil y se alude con frecuencia al concepto de policía. Preocupaba el hecho de que en España los oficios estaban vinculados a la pobreza y que sólo los jóvenes pobres en extremo se entregasen al aprendizaje de uno a cambio de actuar como criado y tener comida. Luego ese joven pasaba a maestro "con la misma miseria que entró" tomando otros aprendices que repetirían su experiencia, "con lo qual se perpetua la ignorancia, y se radica la miseria». Allí tomaba importancia el concepto de policía: era necesario un estricto control en la enseñanza de un oficio para "la general utilidad del Estado» con la mejora en la producción, aumento del comercio y disminución de las importaciones ${ }^{91}$. En el Plan de Ordenanzas para el colegio de artífices plateros de la Corte, incluido en las Memorias, se hacía referencia al control y policía de manera detallada; además de la necesidad de una educación respecto del oficio pero también referida a la calidad de ciudadano. Los maestros debían encargarse de proporcionar educación al aprendiz, como artista y como ciudadano para "los progresos del arte y el bien general de la nación» ${ }^{92}$.

88. Memorias de la Sociedad Económica de Madrid, Memoria sobre el recogimiento y ocupación de los pobres presentado en Junta General Marzo 1778. Madrid: Antonio de Sancha Impresor de la Sociedad, 1780, Tomo 3, pp. 5-6; 10-11.

89. Trueba Mira, Virginia. El claroscuro de las luces: escritoras de la Ilustración española. Editorial Montesinos, 2005, pp. 49-50.

90. Usoz OTAL, Javier. "La nueva política Ilustrada y la esfera pública: las introducciones a la economía en el siglo XVIII español». Revista de Estudios Políticos (nueva época), julio-setiembre 2011, 153, pp. 11-46.

91. Memorias de la Sociedad Económica de Madrid, Memoria sobre el arte de la Platería y ordenanzas para el Colegio de Plateros de Madrid, por el Señor Don Pedro Dabout. Madrid: Antonio de Sancha Impresor de la Sociedad, 1781, tomo 4, pp. 11; 30.

92. Debían cuidar que viviera con honestidad y en cumplimiento de sus obligaciones de buen cristiano; para cada obrador era imperativo fijar los días de trabajo y los días libres, los días de oír misa, las horas de trabajo matutinas y vespertinas las fijaban las juntas gubernativas en función de las estaciones del año. Memorias de la Sociedad Económica de Madrid, Memoria sobre el arte de la Platería, pp. 88-89. 
REGENERACIÓN, ECONOMÍA POLÍTICA Y EDUCACIÓN EN LA MONARQUÍA ESPAÑOLA DEL SIGLO XVIII..

Los ejemplos de este apartado resultan de suma importancia como acercamiento a un concepto de educación en relación al avance del liberalismo económico, donde las reflexiones de Campomanes son clara muestra de un lenguaje atravesado por la economía: la educación como norma, como parte de una decisión política para todos los individuos desde la niñez con el fin de evitar la "Ociosidad” perjudicial a la economía. Una educación asociada al trabajo y el comercio como motor de la actividad económica. En ese contexto el concepto de policía en la formación se hacía imprescindible en el avance de un pensamiento económico liberal que se vio profundizado por otros pensadores como Jovellanos. Las Sociedades que adoptaron justamente el calificativo de «económicas» se convirtieron en promotoras de una educación con formación práctica para moldear ciudadanos «útiles» sin descuidar, por tanto, el acento en el poder de policía. Tales instituciones evidencian, por otra parte, cómo el pensamiento económico pudo canalizarse y llegar a la comunidad con una educación práctica y aplicada.

\section{EDUCACIÓN Y LEYES DE LA ECONOMÍA: CONCEPTOS DE OCIO, FELICIDAD Y BIEN GENERAL. EDUCACIÓN COMO PROYECTO INTEGRAL}

En el contexto de reformas universitarias, una reflexión desde las leyes de la economía con previsiones sobre educación puede verse en Joaquín Dánvila y Villarrasa, catedrático de Filosofía y Derecho en el Seminario de Nobles de Madrid y miembro del claustro de catedráticos de Leyes y Cánones en la Universidad de Valencia. En su interpretación económica de la historia, el hombre dirigía sus acciones para lograr la felicidad en una sociedad civil donde el cuarto estadio de evolución correspondía al comercio ${ }^{93}$. Desde 1767 su pensamiento tomó auge en los círculos ilustrados e inspiró a otros interesados en el concepto de sociedad civil, cuando ya circulaba el término "économie» de Rousseau incluido en la Encyclopedie ${ }^{94}$ Villarrasa manifestaba su interés no solo por la economía, sino también por la falta de jurisconsultos que interpretasen las leyes económicas con

93. Aguilar PIÑal, Francisco. Bibliografía de autores españoles del siglo XVIII. Madrid: Consejo Superior de Investigaciones Científicas. Instituto Miguel de Cervantes, 1984, tomo 3 D-F, p. 14; AZNAR I GARCíA, Ramón. Familia, derecho y religión: Francisco Antonio Cebrián y Valda (1734-1820). Valencia: Universidad de Valencia, 2011, p. 40; HerR, Richard. The eighteenth century revolution in Spain. Princeton: Princeton University Press, 2015, pp. 53-54; SÁNCHEZ Blanco, Francisco. El absolutismo y las luces en el reinado de Carlos III. Madrid: Marcial Pons Historia, 2002, pp. 204-205.

94. Portillo VAldés, José María. "Constitucionalismo antes de la Constitución. La Economía Política y los orígenes del constitucionalismo en España». En GARCía MonERRIs, Encarna y Cármen (eds.). Guerra, Revolución, Constitución: 1808 y 2008. Valencia: Universitat de València, 2012, p. 182. En ese sentido establecía "Economie ou Oeconomie, (Morale \& Politique.) ce mot vient de Oikos, maison, et de Nomos, loi, et ne signifie originairement que le sage et légitime gouvernement de la maison, pour le bien commun de toute la famille. Le sens de ce terme a été dans la suite étendu au gouvernement de la grande famille, qui est l'état. Pour distinguer ces deux acceptions, on l'appelle dans ce dernier cas, économie générale, ou politique; et dans l'autre, économie domestique, ou particuliere. Ce n'est que 
una "filosofía práctica" que evitase demoras en la solución de problemas entre particulares. Esta visión permite asociar la Economía Política con el Derecho, en una legislación conveniente para la "felicidad" del país". Asociado a estas ideas presentaba la Ciencia del Comercio como una política novedosa que, al fijar relaciones mutuas entre las naciones europeas, se apartaba de buscar los medios de conservación y defensa de los enemigos para propiciar el aumento de las riquezas con la promoción de la agricultura, las artes y el mismo comercio ${ }^{96}$. A ello agregaba la necesidad de fomentar la población y la agricultura como pilares del crecimiento. En esa perspectiva la educación era fundamental entre los medios para reducir las clases ociosas y hacerlas útiles al relacionarla con la industria y aplicación de los habitantes de un país, causas de la población o despoblación. Remitía su análisis a Gerónimo Ustáriz, quien aseguraba que la despoblación de España no se debía al envío de personas a Indias luego del descubrimiento, sino al alto número de personas ociosas freno para la producción de riqueza. La educación debía cumplir un accionar especial en las Casas de Piedad, respecto de los niños, por lo cual debían diferenciarse netamente de las Casas de Corrección. Los niños huérfanos debían criarse en casas de piedad hasta cumplir los diez años, momento en que ingresaban como aprendices en casas de artesanos para aprender un oficio. La educación debía ser "fuerte y vigorosa", con disciplina severa y austera. Preveía iguales recaudos en la educación de las niñas y aún mayores para acostumbrarlas al trabajo continuo y periódico, a labores propias de su estado e inculcarles las virtudes de su sexo: "el recato y la modestia». En definitiva, la educación era la acción de «acostumbrar a los hombres a aquel género de vida que sea más útil para ellos, y para los demás». Acostumbrar a los ciudadanos a un trabajo diario y periódico era la función primordial de la educación. La educación debía acordarse según un plan que considerase la triple naturaleza del hombre. En primer lugar, vegetable, por lo que debía acostumbrarse a lo útil para su conservación. Luego, sensible y fantástico, y como tal fomentarle sentimientos e ideas útiles para él y su Nación. Por último, racional, y por tanto instruido en las verdades sublimes o cristianas, y aquellas que según su condición lo condujesen a vivir con tranquilidad. La educación promovía el estado intermedio modelo para el pueblo: aquel entre las grandes riquezas y la pobreza expuestas al pecado, ese estado medio que

\footnotetext{
de la premiere qu'il est question dans cet article. Sur l'économie domestique, voyez. "pere de famille"”. Véase: http://portail.atilf.fr/cgi-bin/getobject_?a.34:19./var/artfla/encyclopedie/textdata/IMAGE/.

95. Dánvila y Villarrasa, Bernardo Joaquín. Lecciones de Economía Civil o de El Comercio. Madrid: Joaquín Ibarra Impresor de Cámara de S. M., 1779, pp. I-II.

96. En ese sentido, veía más ajustada la denominación de Economía Civil porque, luego de contemplar los preceptos relacionados con la economía de las familias, proponía las prescripciones necesarias para el desarrollo e ilustración de una nación asimilada a una gran familia. De allí que el concepto se englobaba bajo el título de Economía Civil o Economía de las Sociedades Civiles. DÁnviLA y Villarrasa, Bernardo Joaquín. Lecciones de Economía Civil, p. IV.
} 
podía conservarse con la buena educación ${ }^{97}$. La verdadera felicidad de la Nación era opuesta a su asociación errónea con el lujo. El concepto de "lujo de vanidad» remitía a la división de las clases, de donde nacían el deseo de distinguirse y los caprichos; llenaba de nuevas necesidades inútiles ${ }^{98}$. La importancia de citar a Dánvila radica en su perspectiva de relacionar el comercio, la libertad y la necesidad creciente de educación con la legislación y la jurisprudencia civil como mediadoras entre la oeconomica y la economía civil99.

Si nos detenemos en la educación en correspondencia con la Economía Política y como proyecto integral de reforma desde los estudios elementales hasta los universitarios es necesaria la remisión a la figura de Pablo de Olavide y su propuesta para Sevilla; además de su rol como coordinador de proyecto con intelectuales sevillanos abocados a diferentes aspectos educativos y que fuera objeto de estudio de Marcelin Defourneaux, Francisco Aguirre Piñal y Luis Perdices de Blas. El Plan de Estudios para Universidad de Sevilla de 1768 estuvo acompañado de seis informes sobre la formación de un hospicio general, un seminario general, un seminario de educandas, uno de alta educación para niños y un colegio para estudios de gramática. En 1797 Olavide presentó su escrito El evangelio en triunfo, donde repetía sus ideas sociopolíticas y su pensamiento sobre reforma educativa y agraria. El proyecto bregaba por una educación secularizada, no escolástica, donde los saberes de las ciencias prácticas eran ajenas a la tradición de las órdenes regulares y la vida ascética. Debe agregarse su proyecto de escritura universal del año 1800 con el que pretendía aportar a la fraternidad, la policía, el buen orden, las artes, como el "camino más fácil para el comercio y la ilustración general». Una educación integral que debía estar al servicio de Dios, gloria del Rey, honor de la Nación y bien de la humanidad ${ }^{100}$. Obras escritas por un hombre que combinó tales objetivos con su afán de enriquecerse, influenciado por su formación con los jesuitas, su función pública luego del motín de Esquilache, su carrera intelectual por las cátedras universitarias de teología y, sobre todo, por su incursión en el pensamiento francés ${ }^{101}$.

97. DánVila y Villarrasa, Bernardo Joaquín. Lecciones de Economía Civil, pp. 91-93; 107-109; $111 ; 121 ; 133-134$.

98. DánVila y Villarrasa, Bernardo Joaquín. Lecciones de Economía Civil, pp. 91-93.

99. Véanse mayores precisiones en García MonerRIS, Encarnación y Carmen. Guerra, Revolución y Constitución (1808-2008). Universitat de Vàlencia, 2012, p. 183.

100. Aguilar PIÑAL, Francisco. La Universidad de Sevilla en el siglo XVIII: estudio sobre la primera reforma universitaria moderna. Anales de la Universidad Hispalense. Sevilla, 1969; AGUILAR PIÑAL, Francisco. "La reforma universitaria de Olavide». Cuadernos Dieciochistas, 2003, 4, pp. 31-46; PERDICES DE Blas, Luis. «Pablo de Olavide (1725-1803). El ilustrado». Madrid: Editorial Complutense, 1992; PERDICES DE Blas, Luis. "Pablo de Olavide (1725-1803) a través de sus escritos". Cuadernos Dieciochistas, 2003, 4, pp. 13-30.

101. Defourneaux, Marcelin. Pablo de Olavide ou l'afrancesado (1725-1803). París: Presses Universitaires de France, 1959 (traducido como Pablo de Olavide, el afrancesado. Renacimiento, México, 1965). 
Por último, el cambio conceptual sobresaliente del periodo que resulta un buen ejemplo del modo en que desde la economía se pensó la educación proviene de las reflexiones de Jovellanos que han sido consideradas como pioneras de la teoría del capital humano. El economista Jovellanos es conocido por sus alusiones a la felicidad como concepto paralelo al de educación, una noción que estaba presente en el lenguaje básico de la Economía Política del periodo.

La inflexión en el cambio conceptual de la educación como una de las categorías de inversión en capital humano en Jovellanos fue remarcado por Donald Street. Para Street el pensamiento de Jovellanos puede verse en la misma línea del planteado por T. W. Schultz o Gary Becker, quien como protegido de Campomanes continuó la tendencia hacia el liberalismo económico y se anticipó a la teoría moderna del capital humano proponiendo métodos de financiación. No casualmente sus comentarios más sólidos sobre educación se hallan en su discurso de economía política, Economía Civil, como un ataque a las causas de la decadencia económica española. La educación pública en Jovellanos debía ser la fuente principal de prosperidad social como lo demostraban la experiencia y la razón. Los beneficios públicos derivados de ella justificaban que fuese objeto de política pública. Su conservación como objetivo principal de un buen gobierno garantizaba la prosperidad. La educación era sinónimo de felicidad individual al ser esta sinónimo de prosperidad material ${ }^{102}$. Por lo tanto, la prosperidad pública era la suma de los resultados de la buena fortuna de los individuos de un cuerpo social. Los beneficios externos de la educación eran esperables sobre todo en economías agrícolas pobres como la española del siglo XVIII. Dentro de este concepto de educación englobado en una apreciación propia de la Economía Política, Jovellanos introducía al comercio como clave, junto a la agricultura, la industria y la navegación, de la acumulación de riqueza y su distribución. La educación generaba además una economía más competitiva (en términos de Adam Smith), reducía las tasas de criminalidad y mejoraba el poder militar ${ }^{103}$.

La preocupación de Jovellanos por una nueva ciudadanía ideal a promover desde criterios de utilidad, educación, y aun de entretenimiento, tendía a moldear ciudadanos patriotas ${ }^{104}$.

Jovellanos aportó a la educación de su tiempo con recomendaciones de reformadores en beneficio del Colegio Médico de Salamanca y con su Reglamento para el Colegio Militar de Calatrava en 1790. Para la educación formal estableció en 1795 en Gijón el Real Instituto Asturiano; escuela técnica de estudios de navegación y minería para la industrialización del carbón en Asturias que combinó en

102. De Jovellanos, Melchor Gaspar. "Introducción a un discurso sobre la economía civil y la instrucción pública, 1797». Revista Asturiana de Economía. RAE, 2012, 45, pp. 181-194.

103. StreEt, Donald. "Jovellanos, an Antecedent to Modern Human Capital Theory". History of Political Economy. Duke University Press, 1988, 20, 2, pp. 191-206.

104. Álvarez Barrientos, Joaquín. "Lo que Jovellanos pensaba de las novelas». Cuadernos Dieciochistas. Ediciones Universidad de Salamanca, 2010, 11, pp. 55-68. 
su plan de estudios las ciencias exactas y naturales con las humanidades; verdadero ejemplo del énfasis en el capital humano y diferenciado de las instituciones escolásticas de su tiempo ${ }^{105}$.

Algunas interpretaciones situaron al lapso entre 1780 y 1790 como aquel en que la economía política se fortaleció como vehículo para la asimilación de los mensajes de la modernidad ilustrada con el fomento de una educación integral y para el bien general. En ese trayecto con inicio en la economía política y culminación en lo político en la primera Constitución española -producto del constitucionalismo ilustrado de 1810 a 1812-, las sociedades económicas siguieron actuando como centros de difusión pedagógica y así lo expresaban sus miembros: «Buscamos examinar los verdaderos principios de la economía política para aplicarlos cuidadosamente a la prosperidad de la Nación... Es el bien general el que buscamos, cercenando a nuestro propio descanso el tiempo que empleamos en estas tareas». Por ello la difusión y enseñanza gratuita de la ciencia económica, aunque se hacía hincapié en la necesidad de una educación que fuese integral ${ }^{106}$. Esa educación integral, vista como camino a la felicidad general en Jovellanos (activo participante en sociedades económicas como la madrileña, sevillana y vascongada), bregaba por un entrenamiento que incluyera a los aprendices, en continuidad con la línea planteada por Campomanes, lejos del sojuzgamiento de capataces ignorantes, de modo que pudiesen desarrollar su capacidad productiva ${ }^{107}$.

La legislación distaba de promover mejoras educativas con la profundidad que los pensadores las proponían desde diversos ámbitos con elaboraciones cada vez más complejas. En materia universitaria, y ante el diagnóstico de decadencia general, Felipe V había ya fijado en 1711 los concursos para cubrir cátedras con indicación de atender al mérito de los candidatos en lugar del turno ${ }^{108}$. No obstante, los principales cambios tuvieron que ver el reforzamiento del rol del censor regio para controlar contenidos contrarios a la fe, al Rey o la moral y la incorporación de reformas con lineamientos propios de la ciencia moderna topó con la resistencia de los claustros escolásticos, especialmente reticentes en el caso

105. STREET, Donald. «Jovellanos, an Antecedent to Modern Human Capital», p. 197.

106. Memorias de la Sociedad Económica de Madrid, Introducción al primer volumen de memorias de la Sociedad Económica de Madrid, 8 de abril de 1780, Madrid: Antonio de Sancha Impresor de la Sociedad, tomo 1, 1780, p. V.; Oración gratulatoria que dixo el ilustrísimo señor don Pedro Rodríguez de Campomanes el 16 de setiembre de 1775. Madrid: Antonio de Sancha Impresor de la Sociedad, tomo 2, 1780, p. 38; Portillo VAldés, José María. "Constitucionalismo antes de la Constitución. La Economía Política y los orígenes del constitucionalismo en España». En GARCía MONERRIs, Encarna y Cármen (eds.). Guerra, Revolución, Constitución: 1808 y 2008. Valencia: Universitat de València, 2012, pp. 180-181.

107. STREET, Donald. "Jovellanos, an Antecedent to Modern Human Capital Theory». History of Political Economy. Duke University Press, 1988, 20, 2, p. 198.

108. Novísima Recopilación de las leyes de España, Libro XVIII, Título 9, Ley VI, p. 62. 
de Salamanca ${ }^{109}$. Desde el punto de vista de reformas disciplinarias se incluía una amplia mención de reglamentación de la asistencia a clases, los horarios, el orden en las explicaciones, duración de las cátedras y entre otras más la expresa mención de que «los cursos ganados en Conventos, Colegios ó Seminarios particulares no sirvan para recibir grado alguno" ${ }^{110}$.

Respecto de las primeras letras en 1780 se creó el Colegio Académico para su «adelantamiento y mayor perfección». El objetivo principal era "fomentar con trascendencia á todo el Reyno la perfecta educación de la juventud en los rudimentos de la Fe Católica, en las reglas del bien obrar, en el ejercicio de las virtudes, y en el noble Arte de leer, escribir y contar; cultivando á los hombres desde su infancia y en los primeros pasos de su inteligencia, hasta que se proporcionen para hacer progresos en las virtudes, en las ciencias y en las artes, el ramo más interesante de la Policía y Gobierno económico del Estado» ${ }^{111}$. Por otro lado, la Real Cédula de Carlos III de julio de 1781 es considerada como el inicio de la obligatoriedad de la enseñanza primaria en España. En 1783, se ordenó el establecimiento de escuelas gratuitas para la educación de las niñas por las grandes utilidades que las escuelas gratuitas aportaban a la "causa pública»; tarea fundamental para asegurar jóvenes aplicadas para la posteridad ${ }^{112}$.

En 1788 se profundizaron las medidas para que los corregidores y justicias aumentaran el control sobre los maestros de primeras letras en el cumplimiento de su función y para que tuviesen "las calidades que se requieren». Ello era necesario pues la primera educación de los niños importaba tanto a la religión como al Estado, porque "las primeras impresiones que se reciben en la tierna edad duran por lo regular toda la vida” y tanto más aún cuando la mayor parte de los niños no recibían otra instrucción cristiana y política que la de las escuelas. Los maestros de primeras letras debían cumplir con exactitud su función, no solo en cuanto a enseñar primeras letras con cuidado y esmero, "sino también y mas principalmente en formarles las costumbres, inspirándoles con su doctrina y exemplo buenas máximas morales y políticas" ${ }^{113}$.

En materia legislativa entonces las reformas continuaban enfatizando la disciplina, el control, la censura y la prevención del regicidio. En relación directa con

109. PerRupato, Sebastián. "Tradición y modernización en torno a la cuestión educativa de la segunda mitad del siglo XVIII. Avances de secularización en el Plan General de Estudios para la Universidad de Salamanca (1771)». Cabás. Universidad de Murcia, 2014, 11, pp. 71-84.

110. Novísima Recopilación de las leyes de España, Libro VIII, Título 6, Leyes VI a XV, pp. 41-44.

111. Novísima Recopilación de las leyes de España. Libro VIII, Título 1, Ley III, p. 3.

112. Novísima Recopilación de las leyes de España. Libro VIII, Título 1, Ley X, pp. 9-11. VILLAMARIN NAVARRO, Helena y REDER GADOw, Marion. "Política educativa ilustrada: una visión comparada de la fundación de escuelas de primeras letras (siglo XVIII)". Americanía. Revista de Estudios Latinoamericanos, Nueva Época. Sevilla, enero-junio 2015, 1, p. 66.

113. Novísima Recopilación de las leyes de España, Libro VIII, Título 1, Ley VIII, p. 8. 
la educación prescribían la gratuidad, la calidad de los maestros y la formación en la virtud con el saneamiento de las costumbres como objeto de la causa pública.

A la Sociedad Económica Matritense de Amigos del País le correspondió la confección del reglamento para las escuelas gratuitas de la Corte, pero cabe mencionar que su rol, y el de las sociedades económicas en general, continuaba vigente a fines del XVIII. Mantenían la participación de las mujeres y por medio de ellas vehiculizaban debates y escritos sobre educación femenina; común en la agenda de discusiones de toda la Europa ilustrada aunque en España su repercusión fuera menor en comparación con otros espacios como Gran Bretaña o Francia ${ }^{114}$. En el caso de la Matritense, además de la mencionada condesa de Montijo fue fundamental hacia fines de siglo la labor de Josefa Amar y Borbón ${ }^{115}$. El impulso de las actividades pedagógicas de estas sociedades no disminuyó después del siglo XVIII prolongándose durante el siglo siguiente y, en algunos casos, hasta el subsiguiente ${ }^{116}$.

Mientras tanto, en la esfera pública, una publicación periódica ilustrada como el Correo de Madrid reflejaba la desconfianza frente a la educación particular en un discurso incluido en el ejemplar de mayo de 1789, que discurría sobre los beneficios de la educación pública frente a la privada y en la necesidad de unir la virtud a la educación. Al concepto de educación equiparaba el de bien público: ambos iban juntos, una mala educación inutilizaba a millares; una buena significaba apoyos y recursos para la patria ${ }^{117}$. El discurso proclamaba como fin de la educación hacer al hombre útil a la sociedad y grato a sí mismo ${ }^{118}$. Como telón de fondo las referencias eran la idea de progreso y la felicidad: la felicidad como consecuencia directa del progreso: la felicidad material lograda con los adelantos técnicos coexistía con la verdadera felicidad, la moral ${ }^{119}$. Un ejemplo claro de la presencia a nivel popular de la perspectiva de futuro y progreso típica del sujeto

114. CALderón EsPaña, María Consolación. "Presencia de la mujer en las Reales Sociedades Económicas de Amigos del País (1775-1808)». Foro de Educación, 2010, 12, pp. 185-231.

115. López CoRdón, María Victoria. "Los estudios históricos sobre las mujeres en la Edad Moderna: estado de la cuestión». Revista de Historiografía (RevHisto), 2015, 22, pp. 147-181.

116. CALDERÓN EsPAÑA, María Consolación. «D. G. Lobe y sus ideas educativas: comentario a la memoria sobre instrucción pública dirigida a la Real Sociedad Económica Gaditana de Amigos del País». Cuestiones Pedagógicas: Revista de ciencias de la Educación, 2002, 16, p. 166.

117. Correo de Madrid (o de los ciegos). Discurso sobre la educación. Madrid: Imprenta Josef Herrera, 1789, tomo 5, p. 2050; CANTOS CASENAVE, Marieta. "De delectare et prodesse y otros propósitos periodísticos. Los casos de La Pensadora Gaditana (1763), La Academia de Ociosos (1763) y el Correo de Madrid o de los Ciegos (1786)". Cuadernos de Ilustración y Romanticismo, 1999, 7, pp. 55-74.

118. La educación debía tender a la virtud bien entendida: "Aunque en nuestra educación se ve que el vicio se castiga y persigue... no basta esto solo, es menester que nuestra juventud aprenda a distinguir y conocer la virtud por sus propiedades». La educación debía promover las buenas costumbres, las "virtudes por las quales Griegos y Romanos se hicieron tan famosos". Correo de Madrid (o de los ciegos). Discurso sobre la educación, pp. 2052; 2055.

119. Labrador Herráiz, Cármen y De Pablos Ramírez, Carlos. La educación en los papeles periódicos, p. 20. 
moderno, con utilización de conceptos propios del cambio de percepción de la Modernidad $^{120}$.

Quizás uno de los conceptos de la época más acabado que podamos citar para concluir es el que entre 1792 y 1793 el conde de Cabarrús refería en sus cartas dirigidas a su amigo Jovellanos:

"La educacion comprehende, ademas de los primeros rudimentos de la infancia, todas las influencias de nuestra vida, la de las cosas, de los sucesos, de los hombres, las del clima, como las del gobierno, lo que vemos, como lo que oimos; pero es menester ceñirse en campo tan dilatado, y no descuidar por la indagacion de una perfeccion quimérica el bien que es hacedero y fácil.. En sus escritos cobraba fuerza la idea de educación nacional y seglar: "La enseñanza de la religion corresponde á la iglesia, al cura, y quando mas á los padres; pero la educacion nacional es puramente bumana y seglar, y seglares han de administrarla" ${ }^{121}$. En cuanto a su financiación: "así bastarán ó sobrarán las dotaciones de la educacion actual, mejor administradas, y aplicadas á las varias educaciones que en el estado se necesitan». La educación igualitaria era prioritaria para la ansiada regeneración: "En fin, á una educacion, ó nula ó dañosa, que sacrifica millares de individuos á la holgazanería y á la corrupcion, aunque algunos pocos triunfen de ella, yo propongo substituir otra que proporcione á todos las mismas ventajas, aunque algunos las malogren. Es fácil ver la diferencia de efectos: las excepciones de hoy serán la regla de entónces» ${ }^{122}$.

Sobre el cierre del siglo XVIII la política de crear un nuevo orden continuó con disposiciones de Carlos IV. En 1791 se crearon ocho escuelas públicas de la Corte, una en cada uno de los ocho cuarteles de Madrid, con el título de Escuelas Reales con inclusión de una especial que se trasladara por los Reales sitios para enseñar a los hijos de la comitiva del rey. Se fijaban veinticuatro «leccionistas» para impartir lecciones sin que nadie más pudiese hacerlo, aun cuando fuere clérigo o alguna otra dignidad ${ }^{123}$. Nadie podía regentear ni tener escuela pública o secreta en la Corte, aun cuando tuviere el título de maestro profesor del Supremo Consejo de Castilla para enseñar primeras letras en todo el Reino si no había obtenido el puesto por vacante en alguna de las escuelas establecidas ${ }^{124}$.

Por último, se ratificó la autoridad de la Real Academia de la Lengua a la vez que se contemplaba la necesidad de atender a la población de menores recursos en su acceso a la lectura y escritura. En todas las escuelas del Reino se debía enseñar a los niños su lengua nativa sin estar admitido estudiar latín hasta que

120. Refleja las reflexiones de Koselleck, Reinhard. Futuro Pasado. Para una semántica de los tiempos históricos. Barcelona: Paidós, 1993, pp. 21-40.

121. CONDE DE CABARRús. Cartas del Conde de Cabarrús al señor Gaspar de Jovellanos sobre los obstáculos que la naturaleza, la opinión, y las leyes oponen a la felicidad pública. Burdeos: Imprenta Lavalle, 1820, p. 90.

122. Conde de Cabarrús. Cartas del Conde de Cabarrús, p. 83; 91; 94; 112.

123. Novísima Recopilación de las leyes de España, Libro VIII, Título 1, Leyes IV y V, pp. 3-5.

124. Novísima Recopilación de las leyes de España, Libro VIII, Título 1, Leyes II, p. 3. 
constara estar formado en la gramática española ${ }^{125}$. La instrucción se completaba con ortografía, lectura en base a un «libro de buena doctrina, de buen lenguaje y corto volumen, que pueda comprarse con poco dinero; porque la mayor parte de los que concurren á las escuelas son pobres» ${ }^{26}$.

Sobre finales del siglo XVIII, entonces, la legislación avanzaba con modificaciones paulatinas y conceptualizaciones escasas en comparación con las reflexiones intelectuales en circulación que nos permiten hallar conceptos de educación con diversos matices y profundidad; proyectos de reformas integrales y avances de conexión entre Economía Política y educación que se convirtieron incluso en antecedentes de desarrollos teóricos importantes de gran influencia en los siglos posteriores, tal fue el caso de la teoría del capital humano, por citar un ejemplo.

\section{CONCLUSIÓN}

A lo largo de este trabajo hemos intentado un acercamiento al concepto de educación con especial atención a algunas de las tantas y variadas fuentes producidas a lo largo del siglo XVIII español que permiten indagar en el sentido propuesto. Se consideraron documentos oficiales como las cédulas reales de la Monarquía Hispánica, publicaciones de circulación popular, documentos de instituciones claves en la transmisión del pensamiento económico como las sociedades económicas de amigos del país y algunas de las principales obras de los intelectuales ilustrados que circulaban en diferentes espacios de sociabilidad a la vez que sirvieron de informes, varios de ellos, para la Corona española. En consecuencia, los componentes para construir un campo semántico en torno al concepto de educación en el siglo XVIII español son abundantes, en especial a partir de la segunda mitad del siglo en que se incrementaron además las medidas normativas concretas de la Corona española; amén de las reflexiones teóricas, en un proceso de secularización y modernización que no obstante mantuvo pervivencias del sistema tradicional dentro del nuevo esquema que se buscaba lograr por medio de un reacomodamiento del marco regulatorio del sistema educativo.

Hasta 1750 se sostuvo la normativa vigente en materia educativa desde los siglos XV, XVI y XVII con ciertas modificaciones del siglo XVIII concernientes a la educación de la nobleza para su servicio a la Patria y otras para el examen de maestros de primeras letras, sin menciones expresas que permitan delinear un concepto de educación de mayor elaboración o finalidad general. Tampoco se observa en los ilustrados analizados profundidad en la delimitación de un concepto de educación. La necesidad de jerarquizar el concepto de comercio como

125. Sobre la enseñanza de la gramática: GARCÍA FOLGADO, María José. La gramática española y su enseñanza en la segunda mitad del siglo XVIII y principios del XIX (1768-1815). Tesis doctoral. Director: María José Martínez Alcalde. Valencia: Universitat de València, Servei de Publicacions, 2006.

126. Novísima Recopilación de las leyes de España, Libro VIII, Título 1, Ley II, p. 4 
principio civilizador y de reordenamiento de los reinos de la Monarquía Hispánica le dieron prevalencia a su consideración, y muchos pensaron la regeneración como paralela al fomento del comercio en cuanto motor del progreso; junto a la educación como herramienta.

Debe subrayarse el aumento de la militarización para una instrucción con sentido patriótico y el ingreso de jóvenes de sectores mercantiles en ascenso junto a los nobles a ser educados para un mejor servicio a la Corona. No obstante, los cambios de concepción no se reflejaban en la definición que circulaba por medio del diccionario de la Real Academia Española, institución dependiente de la Corona, con un concepto de educación sin referencias explícitas a contenidos políticos o religiosos, refiriendo sólo a la instrucción, doctrina y amaestramiento en los primeros años de la niñez.

La segunda mitad del siglo XVIII, en especial a partir de la década de 1760, aumentó la producción y complejidad semántica, a la par de las medidas normativas. La educación como instrucción racional circulaba por la prensa escrita, la vanidad como contraconcepto a desterrar para lograr la formación de hombres íntegros. El pensamiento ilustrado asociado a la economía política ofrece el mayor espacio para el análisis semántico. Bajo el objetivo de restauración la educación como concepto se construyó de manera dinámica en contraposición a otros como vicio, lujo negativo, ocio o mendicidad. En paralelo, se detectan los conceptos de felicidad, utilidad, orden, virtud, norma, política, premio, moral, lujo positivo, comercio o policía; estos dos últimos, sobre todo, como instrumentos unidos a la educación para la regeneración de la monarquía española.

El concepto de educación se complejizó en la legislación en complemento con el de policía y el gobierno económico del Estado, reflejo de un escenario donde la educación pasó a ser herramienta para la causa pública, la utilidad, la posteridad y para el aporte de jóvenes virtuosos y aplicados; piezas claves motorizadas por el papel regulador del comercio y el rol inspirador de la economía política. Los escritos de discusión sobre temas educativos no sólo se encontraban en la España dieciochesca a través de las páginas de las obras de pensadores ilustrados, al servicio o no de la Corona. Las memorias de las sociedades económicas de amigos del país prueban su función pedagógica, de debate y de circulación, al igual que publicaciones más informales como los periódicos de lectura popular donde se manifestaban reflexiones sobre la vigencia de la educación doméstica frente al anhelo de una educación pública e integral, entre otras inquietudes.

Como rasgo notorio es de remarcar que los conceptos sobre educación analizados en las reflexiones ilustradas que circulaban en la esfera pública por distintos medios impresos presentaban un nivel de elaboración y complejidad mucho mayor del que puede hallarse en el corpus legal recorrido; y la conexión con la Economía Política fue haciéndose más estrecha a través de los años perfilándose la antinomia progreso-industria-utilidad frente a ociosidad-decadencia-vagancia donde la educación vio acentuado su rol instrumental. 
REGENERACIÓN, ECONOMÍA POLÍTICA Y EDUCACIÓN EN LA MONARQUÍA ESPAÑOLA DEL SIGLO XVIII...

Construir un campo semántico en torno al concepto de educación en los términos señalados es una labor compleja por la multiplicidad de variables en juego y la vasta producción frente a la que nos hallamos para el análisis. No obstante, estas páginas intentan conformar un acercamiento preliminar para posteriores lecturas. Debimos escoger entre los tantos conceptos y fuentes disponibles, seleccionando aquellos que pudiesen ofrecer un panorama tentativo del riquísimo siglo XVIII español y conscientes de la posibilidad de miradas alternativas sobre el tema.

\section{BIBLIOGRAFÍA}

Aguilar PIÑAL, Francisco. La Universidad de Sevilla en el siglo XVIII: estudio sobre la primera reforma universitaria moderna. Anales de la Universidad Hispalense. Sevilla, 1969.

Aguilar Piñal, Francisco. Bibliografía de autores españoles del siglo XVIII. Madrid: Consejo Superior de Investigaciones Científicas. Instituto Miguel de Cervantes, tomo 3, 1984.

Agullar y PiÑal, Francisco. El académico Cándido María Trigueros (1736-1798). Real Academia de la Historia, 2001.

Aguilar PiÑAl, Francisco. "La reforma universitaria de Olavide». Cuadernos Dieciochistas, 2003, 4, pp. 31-46.

ÁLVAREZ BARRIENTOS, Joaquín. «Lo que Jovellanos pensaba de las novelas». Cuadernos Dieciochistas. Ediciones Universidad de Salamanca, 2010, 11, pp. 55-68.

Álvarez De Miranda, Pedro. "Las academias de los Novatores». En Rodríguez, Evangelina (coord.). De las Academias a la Enciclopedia: el discurso del saber en la modernidad, 1993, 263-300.

Álvarez De Miranda, Pedro. "La época de los novatores, desde la historia de la lengua». Studia Historica. Historia Moderna, 14, 1996, pp. 85-94.

Álvarez De Miranda, Pedro. "La revolución de los conceptos». En Ramos Santana, Alberto y ROMERO Ferrer, Alberto (coords.). Cambio político y cultura en la España de entresiglos, 2008, pp. 201-218.

ANDÚJar CASTILlo, Francisco. «El Seminario de Nobles de Madrid en el siglo XVIII. Un estudio social». Cuadernos de Historia Moderna. Anejos, 2004, 3, pp. 201-225.

ARTOla RENEDO, Andoni. "Reflexiones sobre la práctica del regalismo: gracia regia y alta carrera eclesiástica durante el reinado de Carlos III (1759-1788)». Hispania Sacra, juliodiciembre 2013, LXV, Extra II, pp. 253-282.

Astigarraga Goenaga, Jesús. "Diálogo económico en la "otra" Europa. Las traducciones españolas de los economistas de la Ilustración napolitana (A. Genovesi, F. Galiani y G. Filangieri)». Cromohs: Cyber Review of Modern Historiography, 2004, 9.

AstigarRaga Goenaga, Jesús. "André Morellet y la enseñanza de la economía en la ilustración española. La "Memoria sobre la utilidad del establecimiento de una escuela de comercio"». Cuadernos de Historia Moderna, 2010, 35, 143-173.

Astigarraga Goenaga, Jesús. "Ramón de Salas y la difusión de la fisiocracia en España». Historia Agraria: Revista de Agricultura e Historia Rural, 2010, 52, pp. 75-102.

Astigarraga Goenaga, Jesús. «Las Reflexiones (1761) de Simón de Aragorri y la reforma del comercio atlántico español». Revista de Indias, 2013, vol. 73, 259, pp. 759-788.

Astigarraga, Jesús (ed.). The Spanish Enlightenment revisited. Oxford: Voltaire Foundation, University of Oxford, 2015. 
REGENERACIÓN, ECONOMÍA POLÍTICA Y EDUCACIÓN EN LA MONARQUÍA ESPAÑOLA DEL SIGLO XVIII..

Astigarraga, Jesús y Usoz Otal, Javier. «Del A. Genovesi napolitano de Carlo di Borbone al A. Genovesi español de Carlos III: la traducción española de las Lezioni di commercio de V. de Villava». Cuadernos de Historia del Derecho. Madrid: Universidad Complutense, 2008, 15, pp. 293-326.

Astorgano ABajo, Antonio. «Floridablanca y el jesuita Hervás y Panduro, una relación respetuosa». Res Pública. Universidad de Murcia, Facultad de Filosofía, 2009, 22, pp. 325-362.

AzNar i García, Ramón. Familia, derecho y religión: Francisco Antonio Cebrián y Valda (1734-1820). Valencia: Universidad de Valencia, 2011.

Benigno, Francesco. Las palabras del tiempo. Un ideario para pensar históricamente. Catedra, 2013.

Bolufer Peruga, Mónica. «El arte de las costumbres: una mirada sobre el debate de la civilidad en España a finales del siglo XVIII». Respublica: Revista de Filosofía Política, 2009, 22, pp. 195-224.

Bolufer Peruga, Mónica. «Qué es Ilustración?: nuevas perspectivas historiográficas sobre una vieja pregunta». Debats, 2009, 105, pp. 166-176.

Bolufer Peruga, Mónica. «En torno a la sensibilidad dieciochesca: discursos, prácticas, paradojas». En CANDAU CHACón, María Luisa (coord.). Las mujeres y las emociones en Europa y América: siglos XVII-XIX, 2016, pp. 29-58.

Bolufer Peruga, Mónica; Blutrach, Carolina y Gomis, Juan (eds.). Educar los sentimientos y las costumbres. Una mirada desde la historia. Zaragoza: Institución Fernando el Católico, 2014.

BRETT, Annabel. What is Intellectual History Now? En CANNADINe, David (ed.). What is History now? Palgrave Macmillan Ltd., 2002, 113-131.

BretT, Annabel; Tuldy, James y Hamilton-Bleakley, Holly. Rethinking the foundations of Modern political thought. Cambridge University Press, 2006.

BuRKe, Peter. «La historia intelectual en la era del giro cultural». Prismas. Revista de Historia Intelectual, 2007, pp. 159-164.

CALDERÓn EspaÑa, María Consolación. «D. G. Lobe y sus ideas educativas: comentario a la memoria sobre instrucción pública dirigida a la Real Sociedad Económica Gaditana de Amigos del País». Cuestiones pedagógicas: Revista de Ciencias de la Educación, 2002, 16, pp. 165-184.

CALDERÓn EspaÑa, María Consolación. «Presencia de la mujer en las Reales Sociedades Económicas de Amigos del País (1775-1808)». Foro de Educación, 2010, 12, pp. 185-231.

CAmpoo SchelotTo, Diana. "Danza y educación nobiliaria en el siglo XVIII. El método de la escuela de baile en el Real Seminario de Nobles de Madrid». Bilduma Ars: Revista del Departamento de Historia del Arte y Música de la Universidad del País Vasco, 2015, 5, pp. $158-173$.

Cantos Casenave, Marieta. "De delectare et prodesse y otros propósitos periodísticos. Los casos de La Pensadora Gaditana (1763), La Academia de Ociosos (1763) y el Correo de Madrid o de los Ciegos (1786)». Cuadernos de Ilustración y Romanticismo, 1999, 7, pp. 55-74.

Carabias Torres, Ana María. "Evolución histórica del Colegio Mayor del siglo XIV al XXI». Redex, Revista de Educación de Extremadura, 2013, 5, pp. 66-80.

Chignola, Sandro. "Historia de los conceptos e historiografía del discurso político". Res Pública, 1998, 1, pp. 7-33.

Clavijo y Fajardo, Josef. El Pensador, Imprenta de Joaquín Ibarra, 1762-1767, tomo 5. 
REGENERACIÓN, ECONOMÍA POLÍTICA Y EDUCACIÓN EN LA MONARQUÍA ESPAÑOLA DEL SIGLO XVIII...

CONDE DE CABARRús. Cartas del Conde de Cabarrús al señor Gaspar de Jovellanos sobre los obstáculos que la naturaleza, la opinión, y las leyes oponen a la felicidad pública. Burdeos: Imprenta Lavalle, 1820.

CORREO DE MADRID. Discurso sobre la educación. Madrid: Imprenta Josef Herrera, tomo 5, 1789.

CORTÉS PeÑA, Antonio Luis. "Algunos ejemplos del control gubernamental sobre los jesuitas tras la expulsión». En Mestre Sanchís, Antonio y Giménez López, Enrique (coords.). Disidencias y exilios en la España Moderna, vol. 2, 1997.

Dánvila y Villarrasa, Bernardo Joaquín. Lecciones de Economía Civil o de El Comercio. Madrid: Joaquín Ibarra Impresor de Cámara de S. M. 1779.

De Jovellanos, Melchor Gaspar. "Introducción a un discurso sobre la economía civil y la instrucción pública, 1797». Revista Asturiana de economía. RAE, 2012, 45, pp. 181-194.

De Pedro Robles, Antonio. "Pedro Rodríguez de Campomanes y el "Discurso sobre la Educación Popular"”. Cuadernos Dieciochistas. Universidad de Salamanca, 2006, 7, pp. 197-217.

DE UlLOA, Bernardo. Restablecimiento de las fábricas y comercio español. Madrid: Imprenta Antonio Marín, 1749.

De Zavala y AuÑón, Miguel. Representación al rey nuestro señor Felipe $V$. Madrid: Imprenta Antonio Sanz, 1732.

Defourneaux, Marcelin. Pablo de Olavide ou l'afrancesado (1725-1803). París: Presses Universitaires de France, 1959.

DELGADO CRIADO, Buenaventura. "La educación institucional: la enseñanza doméstica». En Delgado CRIADO, Buenaventura (coord.). Historia de la educación en España y América (siglos XVI-XVIII). Madrid: Fundación Santa María Buenaventura, 1993, vol. 2, pp. 170-174.

EGIDO LóPEZ, Teófanes. «Los antiilustrados españoles». Investigaciones Históricas: Época Moderna y Contemporánea, 8, 1988, pp. 121-142.

EGIDO LÓPEZ, Teófanes. "Carlos III y la primera expulsión de los jesuitas». XX Siglos, 2000, vol. 11, 43, pp. 41-46.

Enciso Recio, Luis Miguel. "La génesis de la Sociedad Económica de Amigos del País de Zamora». Estudis: Revista de Historia Moderna, 1988, 14, pp. 219-244.

ENCISO ReCIO, Luis Miguel. "Las sociedades económicas vistas por los ilustrados. Las opiniones de Campomanes y Jovellanos». Torre de los Lujanes: Boletín de la Real Sociedad Económica Matritense de Amigos del País, 2010, 67.

FERNÁNDEZ SEBASTIÁN, Javier. "¿Qué es un diccionario histórico de conceptos políticos?». Anales, 2004-2005, 7-8, pp. 223-240.

Fernández Sebastián, Javier y Capellán de Miguel, Gonzalo (eds.). Conceptos políticos, tiempo e historia. Nuevos enfoques en historia conceptual. Madrid: Santander Editorial, Universidad de Cantabria, McGraw Hill Interamericana de España, 2013.

FERnÁNDEZ SEBASTIÁn, Javier. "Historia, historiografía, historicidad. Conciencia histórica y cambio conceptual». En Sú́rez Cortina, Manuel (coord.). Europa del Sur y América Latina: Perspectivas Historiográficas, 2014, pp. 35-64.

FREIXAS ALÁs, Margarita. Las autoridades en el primer diccionario de la Academia Española. Tesis doctoral. Director: José Manuel Blecuas Perdices. Universidad Autónoma de Barcelona, 2003. 
REGENERACIÓN, ECONOMÍA POLÍTICA Y EDUCACIÓN EN LA MONARQUíA ESPAÑOLA DEL SIGLO XVIII..

Froesch'Lé-ChOPARD, Marie-Hélène. "Les "Nouvelles ecclésiastiques" et les Lumières (année 1750)». Dix-huitième siècle: revue annuelle de la Société Française d'Étude du Dix Huitieme Siècle, 2002, 34, pp. 82; 77-89.

GarCía Folgado, María José. La gramática española y su enseñanza en la segunda mitad del siglo XVIII y principios del XIX (1768-1815). Tesis doctoral. Director: María José Martínez Alcalde. Valencia: Universitat de València, Servei de Publicacions, 2006.

GARCíA MONERRIS, Encarnación y Carmen. Guerra, Revolución y Constitución (1808-2008). Universitat de Vàlencia, 2012.

HERR, Richard. The eighteenth century revolution in Spain. Princeton: Princeton University Press, 2015.

Iglesias CANO, María del Carmen. Razón y sentimiento en el siglo XVIII. Real Academia de la Historia, 2001.

Koselleck, Reinhart. "Historia conceptual e historia social». En Futuro Pasado. Para una semántica de los tiempos históricos. Barcelona: Ediciones Paidós, 1993.

Labrador Herráiz, Cármen y De Pablos Ramírez, Carlos. La educación en los papeles periódicos de la ilustración española. Madrid: Centro de Publicaciones del Ministerio de Educación y Ciencias, 1989.

LEHMANN, Hartmut y RichTER, Melvin (eds.). The meaning of historical terms and concepts. New studies on Begriffsgeschichte, German Historical Institute, 1996.

LlOMBART ROSA, Vicente. "Economía política y reforma en la Europa mediterránea del siglo XVIII: una perspectiva española». Mediterráneo Económico, Caja Rural Intermediterránea, Cajamar, 2006, 9, pp. 95-113.

LLuCH, Ernest. «El cameralismo más allá del mundo germánico». Revista de Economía Aplicada, 1996, 10, 4, pp. 163-175.

LoPE y Aguilar, Tadeo. Curso de matemáticas para la enseñanza de los caballeros seminaristas del Real Seminario de Nobles de Madrid. Madrid: Imprenta Real, tomo 1, 1794.

LóPEz CORDón CORTEzo, María Victoria. «Los estudios históricos sobre las mujeres en la Edad Moderna: estado de la cuestión». Revista de Historiografía, 2015, 22, pp. 147-181.

Losa SERrano, Pedro y Cózar GutiérRez, Ramón. «Enseñanza y vida académica en la España Moderna. La secularización de la enseñanza en Albacete a partir de la expulsión de los jesuitas». Revista de Historia Moderna, Anales de la Universidad de Alicante, 2002, 20, pp. 3-41.

Mestre SAnchís, Antonio. Pugnas por el control de la Universidad después de la expulsión de los jesuitas, Revista de Historia Moderna: Anales de la Universidad de Alicante, 1988-90, 8-9, pp. 91-118.

Mestre SAnchís, Antonio. "Los novatores como etapa histórica». Studia Historica: Historia Moderna. Ediciones Universidad de Salamanca, 1996, 14, pp. 13-34.

Mestre SAnchís, Antonio. Don Gregorio Mayans y Siscar, entre la erudición y la política. Valencia: Institució Alfons el Magnanim, 1999.

Mestre Sanchís, Antonio y La Parra López, Emilio. Los ilustrados valencianos. En HermosiLLA Pla, Jorge (coord.). La ciudad de Valencia: historia, geografía y arte de la ciudad de Valencia. Valencia: Universidad de Valencia, 2009, tomo 1 pp. 387-391.

NAVIA OsORIO Y VigIL, Álvaro. Rapsodia económico política monárquica. Gijón: Universidad de Oviedo, 1984.

Novísima Recopilación de las leyes de España, Libro VIII, tomo 4, Boletín Oficial del Estado. Madrid, 1805. 
REGENERACIÓN, ECONOMÍA POLÍTICA Y EDUCACIÓN EN LA MONARQUÍA ESPAÑOLA DEL SIGLO XVIII...

OCAMPO SuÁrEZ VALDÉS, Joaquín. "Jovellanos; Ilustración, economía y felicidad pública». Cuadernos Dieciochistas. Ediciones Universidad de Salamanca, 2010, n. ${ }^{\circ}$ 11, pp. 93-117.

OCAMPO SuÁrez VAldés, Joaquín. "Jovellanos: la reconstrucción de un clásico». Estudios de Economía Aplicada, 2014, vol. 32, 1, pp. 83-110.

Peñalver Guirao, Víctor y Riaza Díaz, Paola. "Campomanes y su discurso sobre el fomento de la industria popular». Cartaphilus: Revista de Investigación y Crítica Estética, 2010, 7-8, pp. 219-231.

Perdices De Blas, Luis. Pablo de Olavide (1725-1803). El ilustrado. Madrid: Editorial Complutense, 1992.

Perdices de Blas, Luis. "Pablo de Olavide (1725-1803) a través de sus escritos». Cuadernos Dieciochistas, 2003, 4, pp. 13-30.

PÉREZ ABril, Dora. "Lujo, moda y modernidad en la prensa española del siglo XVIII". Res Publica: Revista de Filosofía Política, 2009, 22, pp. 249-256.

PÉrez García, Pablo y CATALÁ SAnz, Jorge. "Renovación intelectual y prestigio social: novatores, academias e instituciones públicas en la Valencia de finales del siglo XVII y principios del XVII». Saitabi. Universidad de Valencia, 2008, 58, pp. 219-250.

PERrupato, Sebastián. "Tradición y modernización en torno a la cuestión educativa de la segunda mitad del siglo XVIII. Avances de secularización en el Plan General de Estudios para la Universidad de Salamanca (1771)». Cabás. Universidad de Murcia, 2014, 11, pp. 71-84.

PESET REIG, Mariano y José. Gregorio Mayans y la reforma universitaria: Idea del nuevo método que se puede practicar en la enseñanza de las universidades de España. Valencia: Ayuntamiento de Oliva, 1975.

Pocock, J. G. A. "Concepts and discourses. A difference in culture? Comment on a paper by Melvin Richter». En LEHMANN, Harmut y Richter, Melvin (eds.). The meaning of historical terms and concepts. New studies in Begriffsgeschichte. Washington: German Historical Institute, 1996, pp. 52-61.

Pocock, J. G. A. Pensamiento político e historia. Ensayos sobre teoría y método. Madrid: Ediciones Akal S. A., 2011.

Portillo VAldés, José María. «Constitucionalismo antes de la Constitución. La Economía Política y los orígenes del constitucionalismo en España». En GARCía MonERris, Encarna y Cármen (eds.). Guerra, Revolución, Constitución: 1808 y 2008. Valencia: Universitat de València, 2012, pp. 182-194.

POy CASTRO, Raquel. «Regeneración educativa y cultural de la España moderna: reformas monárquicas en educación y el papel de los obispos de la ilustración en el siglo XVIII». Cuadernos Dieciochistas. Universidad de Salamanca, 2009, 10, pp. 185-217.

Real Academia Española. Diccionario de la Lengua Castellana. Madrid: Joaquín Ibarra Impresor de Cámara de S. M. y de la Real Academia, 1783.

Real Academia Sevillana de Buenas letras. Sevilla: Imprenta Josep Padrino y Solís, tomo $1,1768$.

Romá y Rosell, Francisco. Las señales de la felicidad de España y los medios de hacerlas eficaces. Madrid: Imprenta Muñóz del Valle, 1768.

SÁnchez Blanco, Francisco. El absolutismo y las luces en el reinado de Carlos III. Madrid: Marcial Pons Historia, 2002.

SANCHEZ LEÓN, Pablo. «Decadencia y regeneración. La temporalidad en los conceptos fundamentales de la modernidad española». En FERNÁNDEZ SEBASTIÁN, Javier y SÁNCHEZ LEÓN, 
REGENERACIÓN, ECONOMÍA POLÍTICA Y EDUCACIÓN EN LA MONARQUÍA ESPAÑOLA DEL SIGLO XVIII..

Pablo. "Ordenar la civilización: semántica del concepto de Policía en los orígenes de la Ilustración Española». Política y sociedad, 2005, 42, 3, p. 143.

SÁNCHEZ LEÓn, Pablo. "Conceiving the multitud: Eighteenth-Century popular riots and the modern language of social disorder. IRSH. International Review of social History. Cambridge: Cambridge University Press, 2011, 56, issue 3, pp. 511-533.

SMIDT, Andrea. "Bourbon regalism and the importation of gallicanism: the political path for a state religion in Eighteenth-Century Spain». Anuario de Historia de la Iglesia, 2010, 19, pp. 25-53.

Sociedad ECONÓMICA DE MAdrid. Memorias. Antonio de Sancha Impresor de la Sociedad, 1780 , tomos 1,3 y 4.

STREeT, Donald. "Jovellanos, an Antecedent to Modern Human Capital Theory». History of Political Economy. Duke University Press, 1988, 20, 2, pp. 191-206.

TRueba Mira, Virginia. El claroscuro de las luces: escritoras de la Ilustración española. Editorial Montesinos, 2005.

Usoz OTAL, Javier. «La nueva política Ilustrada y la esfera pública: las introducciones a la economía en el siglo XvIII español». Revista de Estudios Políticos (nueva época), juliosetiembre 2011, 153, pp. 11-46.

UzTARIZ, Gerónimo. Theórica y práctica de Comercio y de Marina. Madrid: Imprenta Antonio Sanz, 1757.

VERgara Ciordia, Javier. "Jerarquía eclesiástica y secularización en el "Antiguo Régimen" (1768-1833)». Anuario de Historia de la Iglesia, 2010, 19, pp. 73-94.

VERGARA CiORDIA, Javier y SANCHEZ, Fermín. «Marco documental para el estudio de los colegios y bibliotecas jesuíticas en la España moderna». Anuario de Historia de la Iglesia, 2011, 20, pp. 373-391.

VERGARA CIORDIA, Javier. «Humanidades y profesorado en los jesuitas de Pamplona (siglos XVI-XVIII)». Príncipe de Viana, Ejemplar dedicado a: VII Congreso General de Historia de Navarra, 2011, 2, año 72, 254, p. 449.

Villamarín NAVARRO, Helena y Reder Gadow, Marion. "Política educativa ilustrada: una visión comparada de la fundación de escuelas de primeras letras (siglo XVIII)». Americanía. Revista de Estudios Latinoamericanos, Nueva Época. Sevilla, enero-junio 2015, 1, p. 66.

Von Bielfeld, Jakob. Institutions politiques. Chez Pierre Gosse Libraire de le prince de Stadhouder, tomos 1 y 2, 1760, 789 pp.

WARD, Bernardo. Proyecto Económico en que se proponen varias providencias, dirigidas á promover los intereses de España, con los medios y fondos necesarios para su planificación. Madrid: Imprenta Ibarra e hijos, 1787, 400 pp. 